Article

\title{
Assessing Damage to Archaeological Heritage in Criminal and Administrative Proceedings
}

\author{
Ignacio Rodríguez Temiño $\mathbb{D}$ \\ Conjunto Arqueológico de Carmona, Consejería de Cultura, Junta de Andalucía, Avda. Jorge Bonsor 9 , \\ 41410 Carmona, Seville, Spain; ignacio.rodriguez.temino@juntadeandalucia.es
}

Received: 2 December 2018; Accepted: 28 January 2019; Published: 30 January 2019

\begin{abstract}
The economic assessment of damage to movable and immovable objects considered part of archaeological heritage is a matter of increasing interest, both at the legal level and in terms of government management. The primary reason for this interest is the urgent need to agree on a sound and reliable approach to economically quantifying not so much the cultural value of the damage caused as the civil liability for having caused it in those cases in which it was produced by a harmful human act. Assessment methods require a broad consensus to be considered reliable. The lack of consideration given to this matter has only made the absence of such a consensus more acute. This paper offers a mainly Spanish case-based analysis of the most common valuation methods for both movable and immovable archaeological objects. With regard to movable objects, it examines the problems involved in both the exclusive use of an object's market price as its cultural value and the lack of justification for the chosen valuation system, concluding that current methods are insufficient. This insufficiency, also perceived by the authors of the expert reports used in the analyzed proceedings, has been dealt with arbitrarily. With regard to immovable object, it concludes that the systems currently used to assess the damage to sites are likewise insufficient, despite having been legally acknowledged in some cases. This paper will thus examine the methods used in environmental assessments-whose parallels with archaeological heritage are clear-and proposes that they be adapted for this purpose.
\end{abstract}

Keywords: archaeology; art crime; valuation; archaeological heritage

\section{Introduction}

Given its Latin root (valor, -ōris), there is a certain overlap amongst Romance languages in defining the word 'value' as the quality or qualities for which something is appreciated or considered useful for meeting needs or providing well-being or pleasure. Needless to say, there is a difference between a thing's value and its market price, which need not be the same.

Indeed, the modern cult of the material remains of the past began when the (sometimes contradictory) values that such remains had to offer contemporary society, and which made them worth protecting and safeguarding, were first pointed out by Alois Riegl [1]. The celebrated Austro-Hungarian curator did not include economic value amongst the values that monuments proffered, although what he called 'instrumental' value could be interpreted as practical usefulness against an economic backdrop [1] (pp. $73 \mathrm{ff}$.). Nor did the aesthetic idealism of the first half of the 20th century consider art in economic terms. Benedetto Croce [2] (p. 14) thought that art was pure image, unrelated to the object used as the medium for it. Crocian dogma would have an enormous influence on the sharp distinction drawn between culture and economics: the cultural was priceless and, therefore, could not be economically quantified. By the second half of the last century, however, the economic nature of what had begun to be called 'cultural goods', 'cultural heritage', or 'cultural property' had emerged as a core issue in considerations of the nature of these 'goods' and the most 
appropriate ways of managing them. Today, no one doubts the economic function of cultural objects, but this factor must co-exist alongside others. Decisions regarding such objects, whether made by the authorities responsible for their stewardship or by their owners, must take the long-term consequences into account, especially if they negatively impact the object or its social function.

In fact, the legal nature of these objects arises from their contribution to the intellectual and personal development of those who are exposed to them. This public and social function is not exhausted in the present, but rather has the long-term aim of continuing to provide this service to future generations as well. This consideration of cultural objects as beneficial is also why we feel distress when they are lost, especially when the deprivation is the result of a harmful act, which we consider criminal.

In those cases, reparation requires punishing the perpetrators of the act. To that end, it is necessary to estimate the cost of not only the material aspects of the damaged or destroyed object, but also other intangible aspects, from the historical information it holds to the regard felt for it. To make such an estimate, it is necessary to go back to the economic nature of the object, thereby closing the circle. Although this is true of any object falling within the broad categories into which historical heritage is divided, the particular characteristics of archaeological heritage make it especially vulnerable to damage and destruction and, therefore, worthy of special attention.

The valuation criteria and methods and evidentiary standards used for expert assessments of the value of archaeological heritage are quite similar in common law and civil law countries, albeit with some differences. In this regard, the role of non-legal disciplines as a source of evidence has changed dramatically. Whereas traditionally only conclusions drawn from a handful of 'hard' sciences with well-established credibility were admitted, today other social disciplines have carved out a niche in legal proceedings, disciplines whose evidentiary basis are considered weak and subject to strong doses of interpretation, but which are just as necessary to shed light on the issues dealt with in these cases [3] (pp. 98 f.).

One such discipline is archaeology, whose professionals are asked to assess the cost of the damage done to both movable and immovable archaeological objects. This paper will argue that these expert assessments are performed according to outdated, one-size-fits-all criteria that reflect neither the diversity of legal regimes governing archaeological heritage today, depending on the country, nor the variety of situations in which such reports might be necessary. There is thus an urgent need to review the accumulation of clichés and commonplaces governing how these assessments are prepared.

Despite the interest of this topic, little has been written on it in the academic literature, and the relevant administrative literature is buried away in files that are not easy for the public to access. As a result of this gap, those in a position to make such assessments have to do so almost from scratch, often leading them to repeat the same mistakes or perform routine assessments giving only perfunctory thought to the concepts and methods applied.

Both circumstances have influenced the methodology and purpose of this paper. On the one hand, it is based on a number of cases in Spain, especially judicial experiences in criminal proceedings, ${ }^{1}$ but also administrative proceedings that have required the economic valuation of an archaeological object. On the other, it aims to contribute to the creation of a corpus of literature on these types of assessments that is useful for expert practice, in both administrative and judicial contexts, applicable in both Spain and other countries with diverse legal systems and, possibly, at international bodies as well.

Finally, given the lack of satisfactory practice, it will conclude with a series of recommendations to advance in the establishment of reliable evidentiary standards for assessing the value of damage to archaeological sites and movable objects.

1 All judgements and other Spanish judicial decisions cited in this paper that have been collected by the Centro de Documentación Judicial (Cendoj) (Judicial Documentation Centre) of the Consejo General del Poder Judicial (General Council of the Judiciary) can be consulted online using the Cendoj search engine, entering the identification (Id) code at: http:/ /www.poderjudicial.es / search/indexAN.jsp. 


\section{Legal Bases}

This section will examine the main conceptual bases for the supporting criteria for the subsequent considerations regarding the assessment of the economic value of movable or immovable objects considered to be archaeological heritage.

We should begin with the choice of the name used to designate the object of the legal protection. One way or another, the idea of cultural heritage flows conceptually from the theory of cultural goods developed in Italy in the 1960s, especially by the Franceschini Commission [4]. Unlike the strictly material Crociophilic concept of a 'thing of historical and artistic interest', the Franceschini Commission proposed the concept of a 'cultural good' as any manifestation containing a reference to the history of culture. Given the enormous breadth of this semantic field, M.S. Giannini [5] (pp. 6 ff.) established that cultural goods, properly speaking, must bear witness to the values of civilization. For Giannini, this definition was legally open, meaning its content would have to be sought in other disciplines; however, this dependence did not mean it could not be assumed by law. Giannini also advocated a definition of cultural good based on a material object (entity in the external world), publicly or privately held, on which a certain interest with regard to a social discipline related to history could be predicated. Thus, a second legal nature was conferred upon the material entity, subject to public stewardship. This dual nature explained why a cultural good had a material medium, but was not identified with it but rather merely adhered to it. The testament it bore to the values of civilization made it an immaterial entity (an ideal value) inlaid in one or more material entities [5] (pp. 22 ff.).

It is worth noting that one of the commission's main concerns was looting. In its initial analysis of the status of archaeological heritage, it stressed the widespread devastation of this heritage. The most flagrant case for the commission's members was the destruction of Etruscan and Greek sanctuaries and necropolises by clandestine diggers, for the purpose of engaging in trafficking and illegal export. In accordance with its postulates, the commission argued that the fundamental loss entailed by these practices was not so much that of the objects themselves as " ... la conseguente perdita dei dati di conoscenza storica inerenti ai rinvenimenti, che ne costituiscono il valore essenziale ... " [" . . the consequent loss of the historical knowledge inherent to the finds, which constitutes their essential value..." ] [4] (p. 128).

In Spain, the dominant theories are based on these initial proposals. There has been a shift from a strictly material conception of a legal interest protected by the regulations governing cultural goods to the idea that it is the social function that the legal system assigns these goods that is the object of public stewardship [6]. Such a promotional function would be inconceivable if one did not take into account the immaterial value of the cultural good, for which the object itself is merely the medium. Criminal law doctrine also seems to agree that it is not the objects per se that should be protected, but the ideal value they represent and the social benefit that this value makes possible $[7,8]$.

Meanwhile, archaeological artefacts are regarded as material entities that incorporate the aforementioned immaterial reference to the history of civilization, with the added condition that this information is most effective when it can be recorded in its archaeological context, i.e., in the place of its deposit, whether that be the originally intended site or the site to which it was displaced by post-deposit actions. If this immaterial aspect is stripped from the material object that acts as its medium, the archeological artefact loses much, or even all, of its informative potential.

The regime applicable to archaeological heritage in Spain is conditioned by the fact that it has been considered a public good since 1985. O'Keefe and Prott [9] (pp. 188 ff.) divide regulations on archaeological heritage depending on whether they assert state ownership of such property or merely enforce the behaviors to be followed when new items belonging to the archaeological heritage appear. In their view, state ownership of objects ex lege does not seem to be a decisive factor in ensuring the protection thereof, as such ownership is not necessary to regulate the behavior of the parties who find them. However, in Spain, the thinking is different. The decision to move objects forming part of the archaeological heritage into the public domain, effected under Law 16/1985 on Patrimonio Histórico Español [Spanish Historical Heritage] (hereinafter, LPHE from the Spanish), was almost unanimously 
applauded. This decision was reached following a long legal journey in which, above and beyond the various solutions proposed for the issue of archaeological finds, there was always a deep-seated concern for the preservation of this fragile heritage [10] (pp. 297-330). This fact certainly influences the determination of the economic value of finds, as it precludes direct application of the market price. So far, this legal statute has already had enormous implications for cultural objects in general and for archaeological heritage in particular [11] (p. 62). In economic terms, the second legal nature of this heritage, i.e., the values that endow it with a social function subject to public regulation and that also condition its ownership by interfering with its free availability, is called "cultural capital" [12] (p. 986). Cultural capital is a poor fit for market mechanisms, and it is considered a market failure [13] (p. 53).

It is also worth mentioning certain criminal law aspects, at both the international level and the level of each country. In the sphere of illicit trade, the expected flood of international trafficking in looted archaeological artefacts originating from countries embroiled in armed conflicts has led to the resuscitation of clearly punitive instruments, such as the Convention on Offences relating to Cultural Property (Delphi 1985), which never entered into force. The Council of Europe has opened a new Convention on Offences relating to Cultural Property (Nicosia 2017) for ratification, which, in its own words, "fills a gap in international law, since none of the existing conventions deal with criminal law issues".

With regard to each country's domestic criminal law, the situation is far from homogeneous. In broad terms, there are two main legislative models. In one, the backbone of criminal law is a code covering all criminal offences, whether through the creation of new categories of offences or, more frequently, aggravated subcategories of existing crimes against property. In the other, the various sectoral laws are responsible for categorizing criminal behaviors.

Regardless of the model in force, in all countries the protection of cultural heritage in general, and of archaeological heritage in particular, is bolstered against the most serious potential attackswhether damage, illegal digs, the failure to report chance finds, theft or appropriation-through criminal repression [14].

The essential unlawful content of all these crimes is a potentially or effectively harmful act against a movable or immovable archaeological object, whether on land or underwater, or wilful or negligent disobedience, i.e., a failure to do or refrain from doing something, the result of which negatively affects the objects' conservation. Consequently, the actual wording of the relevant articles varies little from one legal system to the next. Whether the system includes a punitive administrative system to punish mere disobedience and a criminal one to handle serious attacks against archaeological heritage or all acts are dealt with under criminal law, thereby criminalizing behaviors that, in other countries, would be considered mere administrative infractions, depends on the legislation of each country.

In this area, the Spanish case stands out, not only due to the development of a sanctioning administrative law unlike that of any of Spain's neighbors [15] (pp. 69 ff.), but also for the inclusion of two different crimes against archaeological heritage in Article 323 of the Código Penal [Criminal Code] (hereinafter, $\mathrm{CP}$ from the Spanish), according to the revised wording adopted under Organic Law 1/2015, of 30 March 2015. ${ }^{2}$ The article includes two classes of offences: a specific offence consisting of damage affecting, amongst other things, archaeological sites, and another offence specifically referred to as 'archaeological looting', whose exact content has had to be delimited, as its name initially seemed reiterative of the offence of damage. Indeed, the interpretation of this new offence has evolved. At first, some jurists held that it was not an ex novo offence, but rather the concurrence of two existing offences in a single action: the offence of damage to a site coupled with the offence of misappropriation of

2 "1. A prison sentence of six months to three years or a penalty of twelve to twenty-four months will be imposed on anyone who causes damage to property of historical, artistic, scientific, cultural or monumental value, or to archaeological sites, whether on land or underwater. The same punishment will be imposed for acts of looting of the latter. 2. Should especially serious damage have been caused or should property of particularly significant historical, artistic, scientific, cultural or monumental value have been affected, the next highest punishment to that stated in the previous paragraph may be imposed. 3. In all these cases, the judges or courts may order, at the expense of the perpetrator of the damage, the adoption of measures intended to restore the damaged property to the extent possible." 
movable property as a result thereof [8] (pp. $186 \mathrm{ff}$.). However, more recently, this interpretation has been dismissed because the penalty for the new offence of looting is exactly the same as that for the generic offence of damage. Therefore, it cannot refer to the concurrence of two existing offences, as in that case the penalty would have to be steeper due to the existence of two offences in one. The most plausible reasoning to date considers it an entirely new offence, unrelated to the offence of damage. This new offence would include minimally harmful actions that endanger the integrity of archaeological heritage [16] (pp. 181 f.). Under this new interpretation, the new criminal offence could include the use of metal detectors at archaeological sites or in areas where archaeological objects are presumably concealed underground [17] (p. 303). The site does not need to have been granted any sort of official administrative status for the offence to be committed.

It is also worth noting that Spanish law draws a distinction between two separate concepts that is not always made in other domestic legal systems. Specifically, although the Spanish terms daños and perjuicios are usually jointly translated as simply 'damages' in English, technically daños refers to the material damage or injury suffered, whilst perjuicios refers to the losses incurred.

Broadly speaking, in the cases of interest here, 'material damage' refers to the impairment suffered by a movable or immovable object, as a result of a specific event, that destroys it or diminishes or renders useless its original characteristics. However, the criminal content of the expression 'damage to archaeological heritage' is subject to strong doctrinal controversy. According to some, the object's materiality need not be directly affected, and a penalty may be imposed for any act preventing the fulfilment of its social function [18,19]. For others, its material substance must have been at least minimally altered [7]. In light of this important doctrinal conflict, for the purposes of this paper, damage to an archaeological site will be understood to mean that artefacts have been removed throughout the site or from specific areas thereof and, therefore, that both its material substance and the information it holds have been affected, whether due to the removal of archaeological sediment or because archaeological movable objects themselves have been collected, selectively or otherwise, from it. Spanish law provides for both the wilful and negligent commission of such acts.

In contrast, 'losses' are the negative consequences of the harmful act for the owners or users of the good. The parties responsible for the acts are civilly liable for both concepts, and their economic quantification is used to calculate the corresponding compensation [20] (p. 119). Indeed, in addition to Article 323, Articles 109 et seq. CP regulate, in general, the associated civil liability of the person or persons found guilty of a criminal offence with a view to remedying, as far as possible, the damage done. This economic liability tends to be much greater than the penalty that can be imposed for the acts themselves. Its specific amount depends on the expert assessment of the damage done.

A more extensive discussion of the classification of crimes against archaeological heritage under individual country's legal systems and the comparison thereof with the international legal order are beyond the scope of this paper. Suffice it to note, based on the foregoing explanation, that when investigating these crimes, or administrative offences, it is essential to assess the extent and severity of the damage caused, as well as to quantify it economically, in order to properly graduate the penalty and any civil liability or compensations that might be established.

\section{Types of Archaeological Heritage}

Before we enter into other considerations, it would be helpful to take a brief look at the relationship between archaeology and archaeological heritage. So as not to delve too deeply into the discipline's increasingly broad profiles, for the purposes of this paper, archaeology should be understood as the study of human behavior through the recording and interpretation of material culture. This is a broad concept encompassing not only movable and immovable objects and constructions, but also the occupation of the territory and the modification thereof to adapt it to human needs, modifications that include changes in animals and plants and other ecosystem components, both recent and ancient.

Accordingly, for example, Article 40 LPHE provides that archaeological heritage is made up of historical artefacts capable of being studied with archaeological methodology, regardless of whether 
they have been excavated or remain concealed and of whether they are on land or under Spain's jurisdictional waters.

From this perspective, it is no exaggeration to say that we are literally surrounded by archaeological heritage, although in many cases it remains concealed and, thus, unknown. Indeed, the aforementioned definition of archaeological heritage allows for three possible situations, in terms of our knowledge of its existence, again whether it is on land or underwater: known (heritage that has already been excavated or survives due to its monumental nature), presumed (heritage that is known to exist, but has not yet been excavated), and unknown. These situations give rise to certain peculiarities with regard to its legal status and the adaptation of measures intended to protect it. This aspect has concerned lawmakers since the enactment of the first laws aimed at preserving this heritage at the turn of the 19th century. This singularity is also what confers on archaeological heritage the need for a specific legal regime within the general branch of law governing historical heritage. Additionally, the objects comprising archaeological heritage are integrated into landscapes in such a way as to require the joint treatment and management of both, i.e., of the heritage and of the landscape itself. Both are very vulnerable to damage. However, unlike many natural landscape elements, archaeological artefacts are finite and non-renewable, making their destruction irreparable.

The different situations in which archaeological heritage is found have greatly influenced assessments of its value. The same criteria cannot be applied to movable objects as to a site. Nor can the same criteria be applied to an archaeological monument, i.e., an excavated and visitable site, sites that, whilst excavated, cannot yet be visited, and sites that have not yet been excavated. In this regard, the differences between dry-land and underwater archaeological heritage affect only the added costs involved in working on archaeological objects in an environment hostile to human life.

\section{Assessment Methods and Criteria: Case Studies}

In Spain, at least, the phrase 'incalculable value', the response traditionally given by archaeologists when asked to appraise objects found outside the antiquities market or to assess a site's destruction, was redolent of the aforementioned Crocian idealism [21] (p. 71). In Spanish legal practice, one doctrinal camp embraced the concept, after eliminating its nihilistic note, for an eminently practical reason: to move beyond the reference to material values when it came to classifying harmful acts affecting archaeological objects as felonies rather than misdemeanours. This contrivance made it possible to associate the greatest liability provided for by law with the illicit act in question without the need to actually assess the value of the specific damage to the material medium $[22,23]$.

The 2015, reform of the aforementioned Article 323 CP, concerning malicious damage, eliminated the reference to the minimum amount required for such damage to be considered a felony. However, in the case of damage due to gross negligence (Article $324 \mathrm{CP}$ ), a minimum value of $€ 400$ was maintained for the harmful act to be considered a felony.

Although clearly intended to solve a practical problem, this proposal has not ultimately eliminated the need to assess the economic value of the damage, as in the absence of such a valuation it would not be possible to pursue a liability claim against the responsible parties. If the value of the damage is omitted, one runs the risk of its being considered unusual damage, in which case any claim for civil liability would be inadmissible $[21,24]$. Consequently, today, the expression "incalculable value" is used only residually, for exceptional cases in which economic criteria cannot be applied [8] (pp. 206 ff.).

The fight against archaeological looting in Spain, especially since the late 1990s, has required the drafting of expert assessments. Those years saw the first operations against archaeological looting, which were extensively reported in the media. They also brought dizzying figures regarding the value of the seized artefacts, which numbered in the thousands. However, the reports requested from government bodies to support the accusations focused on assessing the economic value of the seized objects, not on the effects of the illegal digging on the sites, even though in many cases the provenance of the pieces found in the illicit collections was known [25]. 
To date, the most spectacular operation has been 'Operation Tertis', in which the Guardia Civil [Civil Guard] seized more than 300,000 archaeological objects [26,27] (Figure 1). However, this approach met with little judicial success, as the judges considered that the prosecution had failed to prove with sufficient clarity the commission of any criminal wrongdoing. The investigation had focused on collections, but lacked 'proof of provenance' or proof that the seized objects were the product of archaeological looting for which the statute of limitations had not run out.

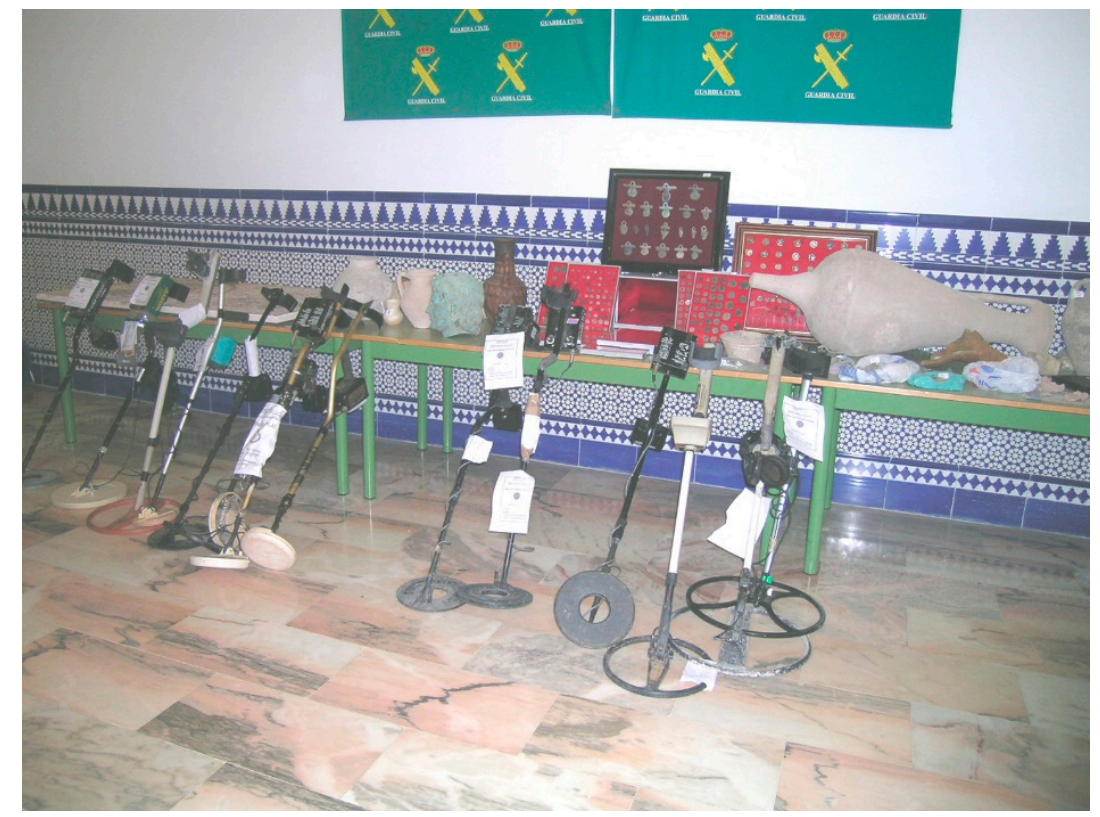

Figure 1. 'Operation Tertis'. Metal detectors seized by the Guardia Civil (photo by the author).

These judicial setbacks sowed confusion not only in the police but also in the cultural authorities, whilst at the same time reaffirming the impunity of the looters. In response to these failed attempts, the criteria used for criminal investigations have been changed. The initial focus is no longer placed on offences of handling stolen goods or on the chain of sales followed by the pieces, but rather on documenting the original theft. The focus of the expert reports has likewise changed. Rather than seeking to quantify the economic value of the seized objects, which is usually quite low, they seek to assess the value of the damage caused to the sites [27].

This path has given rise to two main situations in which expert assessments are used: decontextualized movable objects and sites, usually non-excavated. These assessments are generally made by professionals or experts. However, there is one major anomaly. When the government needs to reward the finders of a chance archaeological find, an assessment committee must be appointed $e x$ professo. Incomprehensibly, assessments in these cases are governed by a very old law, the 1954 Ley de Expropiación Forzosa [Expropriation Act]. That law provides that the committee responsible for assessing the value of archaeological artefacts must consist of three academics, i.e., members of one of the Spanish royal academies [28]. These institutions, which have endured from the Enlightenment era to today, usually play a very marginal role in the country's social and cultural life. The reason this preconstitutional law turned to them is quite simple. For most of the 20th century, Spain lacked a professional cultural administration. It compensated for this by appointing people with sufficient free time to handle routine matters for free, leading to the creation of what has been called the 'honorary administration'. The use of this non-professional administration has been one of the main shortcomings of cultural heritage management in Spain [29] (pp. $576 \mathrm{ff}$.). This situation changed dramatically with the establishment of the autonomous community (regional) governments, which created departments for specialists in archaeological heritage management [30]. Nevertheless, as noted, vestiges of the 'honorary administration' inexplicably remain. 
A critical analysis of these circumstances will help us reconsider the criteria applied to prepare these assessments and address other foreseeable scenarios in the not too distant future. The following sections will examine both situations (decontextualized finds and sites) through the study of specific cases based in Spain.

\section{Decontextualized Movable Objects}

This circumstance is very common in both criminal proceedings involving the seizure of archaeological artefacts and administrative proceedings, mainly concerning rewards for the reporting of chance finds. This analysis will focus on two specific aspects: the advisability of using the market prices of these objects as an absolute reference and the need to justify the methodology used.

Usually, the value of the objects is assessed using the prices on the licit antiquities market. Some laws, such as the 1997 Treasure Act in England and Wales, even require the object's value to be identified as its market price. The Portable Antiquities Scheme uses this same reference for the valuation of metal objects found by detectorists that are acquired by museums or individuals [31,32]. Under Spanish law, it is highly unlikely that a find made with a metal detector will be considered a chance find. Therefore, such finds are not subject to the provisions of Articles 41.3 and 44 LPHE. When a chance find is determined to exist, under Spanish law, the finder is entitled to a reward equal to half the value attributed to it in legal evaluation, to be divided equally between the finder and the owner of the land where it was found, if someone else. Regardless of the questionable nature of this legislative approach, the root of the interpretative problem is what is meant by "legal valuation" [33].

One thing seems clear: market prices in and of themselves are not objective. The licit market for appraising such goods is usually that of auction houses. The role of experts in setting the prices of works of art has been discussed, especially with regard to their biases [34] (pp. $931 \mathrm{ff}$.). If such biases are found in the established and studied art market, they are presumably even greater in the antiquities market. Given the difficulty involved, the precedents of direct sales or platforms for the online sale of goods are also often used, but more research is required on the processes for setting the market prices of archaeological artefacts. Furthermore, unlike, for example, coins, not all archaeological artefacts have an established market and, therefore, catalogued prices.

In truth, in many cases the notion of a market price hides a fiction, as archaeological objects are either virtually unique or, if they were mass produced, finite in number and only exceptionally found in an acceptable state of conservation. Often, the set price exclusively reflects the profit the seller expects to make or the buyer's spending power. Furthermore, this virtual uniqueness of archaeological objects prevents (or largely hinders) the existence of competition. Consequently, in reality these are estimated based on mere opinions and the personal experience of the people responsible for setting them.

When there are no precedents of similar cases, the prices are set taking into account certain criteria, such as the rarity of the piece, the material it is made of or its degree of conservation. Thus, depending on whether the appraisers are working for one of the parties or to advise a judge or court, the valuation can vary considerably, because it is based on highly subjective and largely arbitrary estimates [13] (p. 53). The use of market prices as a reference for the valuation of an archaeological object or set of objects must logically take into account the nature of that object or set. In the case of unique, non-mass-produced objects, such as Roman-era portraits, the emergence of a new one will not significantly affect the price of such objects, for example, at auctions. However, in the case of mass-produced objects, such as coins, the valuation should take into account the number discovered, especially if they are billon coins, as it will affect the price of that type of coin on the antiquities market. To determine the new price, the standard microeconomic concept of 'elasticity of demand' is used, which measures market resilience to oversupply.

As we will see in the case discussed below, these considerations have never been taken into account in the praxis of the valuation of movable archaeological objects.

In Spain, movable archaeological artefacts discovered after 1985, the year the LPHE entered into force, as a result of chance finds or archaeological activities belong to the public domain, i.e., they are 
public property. However, this fact does not seem to have substantially changed the valuation criteria used in administrative and criminal cases in which it has been necessary to assign an economic value to movable archaeological artefacts, or to parts of immovable artefacts rendered movable as a result of their removal from the whole, as in the case of mosaics and pictorial or sculptural decorations. It is difficult to cite specific cases as the expert reports are rarely released. Fortunately, however, in the most important cases, the substantive parts of these reports have been transcribed in the judgements and other judicial resolutions or reported by the media.

There have been many cases of valuations of chance finds made prior to the entry into force of the LPHE in 1985. Perhaps one of the most controversial was that of the Roman villa of Carranque (Toledo), one of whose mosaics was discovered by chance in 1982 [35]. The case generated much controversy due to the Supreme Court's interpretation of the scope of the concept of chance find [33]. However, the aspect of interest here was the applicant's claim that the official valuation $(350,000$ pta or $€ 2,103.50$ ) should be increased because this amount did not reflect the mosaic's 'market value'. Ultimately, in its judgement of 17 January 1992 (Cendoj Id. 28079130011992108820), the Supreme Court found that the mosaic had a market value of $3,470,125$ pta $(€ 20,855.90)$. The most significant aspect of this finding was that the expert valuations were performed using the prices of polychrome mosaics at auction houses as a reference.

The assessments performed in Spain since 1985 have not only failed to incorporate the new legal status of movable archaeological objects, but also have not taken the opportunity to engage in a detailed reflection on valuation methods. In fact, the rationales provided in the expert reports are conspicuously absent.

In 2016, in Tomares (Seville), during works to adapt a park, workers found a set of 19 amphorae filled with Roman coins dating from the third and fourth centuries A.D. [36] There were more than 50,000 in all (Figure 2). The find was widely reported in the media. ${ }^{3}$ [37] Although initially no economic estimates were given, it was soon revealed that the Museo Arqueológico de Sevilla [Archaeological Museum of Seville], to which the coins had been turned over, considered that, as the coins were folles of the emperors Diocletian, Constantine, and Maximian, with a unit price at Sotheby's of $£ 60$ and on eBay of $€ 60$, the finders were due an enormous fortune. ${ }^{4}$ Although the case has not yet been settled, these reports clearly point to major misconceptions.

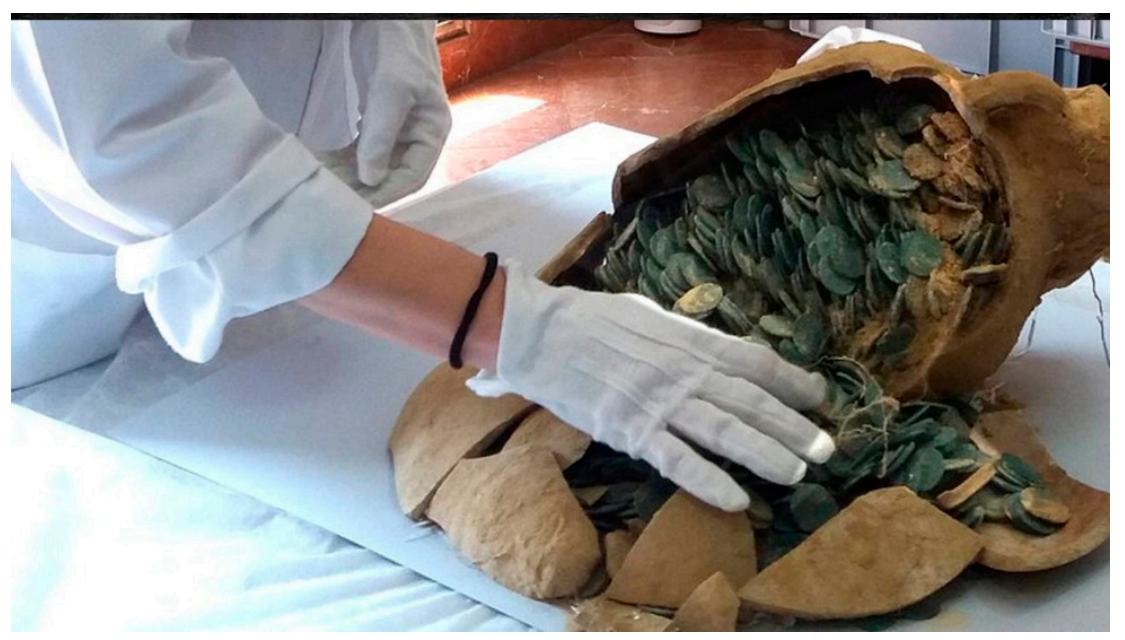

Figure 2. Coins found in Tomares (Seville). One of the amphorae containing coins (photo by the author).

3 On 29 April 2016, El País ran the article, "600 kilos de monedas romanas descubiertas en Tomares" [600 kilos of Roman coins discovered in Tomares]; The Guardian, "Massive $600 \mathrm{~kg}$ haul of ancient Roman coins unearthed in Spain"; Le Figaro, "Un trésor romain découvert par hasard par des ouvriers en Espagne" [Workers in Spain accidentally discover a Roman treasure].

4 See, in eldiario.es, the article 'Los descubridores del tesoro de Tomares pueden reclamar la mitad de su valor' [The discoverers of the Tomares treasure can claim half its value] from 29 April 2016. 
According to news reports, the prices listed in auction house catalogues were used as references without taking into account the fact that these coins are in the public domain and, therefore, not on the market. However, even if that valuation were to be used, other considerations would need to be factored in. First, the prices estimated by Sotheby's or found on eBay were set without taking into account the 50,000 new coins from the find in Seville. If the real market price were to be re-estimated taking the availability of the new coins on the market into account, their economic value would decrease dramatically, due to the exponential increase in the supply and the fact that the market for antique coins lacks the necessary elasticity to absorb this numismatic avalanche.

There are many precedents for such situations. In 1999, as a result of looting, 350,000 porcelain pieces were extracted from the Tek Sing, a 1000-tonne junk, also known as the 'Chinese Titanic', which sunk in 1822 in the waters of the South China Sea. The following year, they were auctioned in Stuttgart (Germany), but the company Ocean Salvage Corporation was greatly disappointed. Half the lots failed to sell, and those that did fetched prices far lower than expected [38].

Additionally, the valuation took only one of the elements surrounding the find into consideration, the coins' market price. Other key aspects, such as their state of conservation, were ignored. The coins seemed to be fused together in large batches, with an acceptable state of conservation in many cases, but in need of intervention and maintenance, costs that should have been taken into account in their valuation.

This same lack of attention to the state of conservation and its economic consequences was also on display in another notable case of underwater looting, this time of the Nuestra Señora de las Mercedes, carried out in 2007 by Odyssey Marine Exploration Inc. [39] in waters of the Portuguese continental shelf. Once the Kingdom of Spain had recovered the coins from the sunken frigate, following civil proceedings in the US courts, ${ }^{5}$ the investment required for the coins' conservation turned out to be far higher not only than their market value but also than that of their weight in silver. To date, 40,000 coins have been restored for exhibition purposes, whilst the rest have been given only a basic stabilization treatment [40]. This adventure, which was a bust for the US company due to the legal actions undertaken by Spain, might have been the ruin of Odyssey altogether had it kept the coins. Or it might have melted them down directly with a view to extracting any potential profit from the sale of the silver. The failure to take into account all the circumstances surrounding the looting operations is one of the reasons why only 1 in 20 treasure-hunting companies stands a chance of making money [41].

In any event, returning to the Tomares case, the main criterion is derived from the fact that the discovered coins belong to the public domain. This means not only that they fall outside the scope of normal legal trade and, therefore, cannot be sold, but also that their contribution to public service must be taken into account as well. This, in turn, means that their social function is linked to their role as a source of knowledge, but also as a museum object. In other words, any decision regarding the ultimate fate of the coins might rationally include the measure of not emptying some of the amphorae so as better to convey the idea of intended concealment. That would make the amphorae containing coins (appropriately consolidated and stabilised in a block to prevent their deterioration) a joint composition endowed with a cultural value different from that of the mere sum of the coins and containers.

Compounding the uncertainty, in some cases prices from illicit market have been taken into consideration. The team responsible for the expert report on the damage sustained to the Chaves cave (Huesca), which will be discussed in greater detail below, has published a method for assessing the value of decontextualized movable archaeological artefacts that combines three sources of information: licit market prices, the value of the insurance for similar pieces held by museums and illicit market prices, primarily collected from online sales. The valuation is calculated based on the confluence of the prices from these sources adjusted through the application of estimated weighting percentages [42].

5 Case No. 8:07-CV-614-SDM-MAP. United States District Court. Middle District of Florida. Tampa Division. Odyssey Marine Exploration, Inc. (plaintiff) v. The Unidentified Shipwrecked Vessel (defendant in rem) and The Kingdom of Spain, The Republic of Peru, et al. (claimants). 
Such formulas are more than a little confusing, as they mix the natures and legal statuses of the movable artefacts and the markets on which they are traded. Archaeological artefacts may have a market price (licit and illicit), but not all monetary references should be taken into account when calculating the economic value of an artefact, especially when it belongs to the public domain. Furthermore, prices from the illicit market, whose regulation is highly arbitrary, should not be considered at all [43].

The fact of belonging to the public domain does not prevent the calculation of an artefact's economic value; it simply distances it from the market price, even when the latter is considered a reference to be taken into account. The most appropriate criterion for assessing value in the case of decontextualized movable artefacts might be to equate it with the price of the insurance required for the loan of such artefacts by one museum institution to another for a temporary exhibition. In establishing that value, it is not necessary to take the market price into account mainly or even, necessarily, at all. The uniqueness of the archaeological artefacts and the respect for authenticity in the museum exhibition would preclude the purchase of similar coins or amphorae on the antiquities market to 'recreate' the composition in case of the total or partial loss thereof. The insured sum is established in accordance with the impairment that not having more of the original coins or a part of them would entail for Spanish historical heritage, based on the methods described below. In fact, what is established is not so much the price of the set of archaeological artefacts, or even the value of the information lost, another common assessment criterion, but the compensation for that loss.

Using insurance prices as the economic value of museumized objects that lack a defined market is a common practise for which there are numerous precedents. In the well-known case of the Colomera Meteorite, the Provincial Court of Madrid ruled against the Consejo Superior de Investigaciones Científicas [Spanish National Research Council] in its judgement of 29 May 2015 (Cendoj Id. 28079370132015100189). In it, it required the Consejo to compensate the discoverer's descendant for an amount calculated based on the value of the insurance purchased when the Spanish institution loaned it to the University of California.

Obviously, whilst the application of this criterion to archaeological artefacts is not inappropriate, it is novel. Consequently, the expert report should include an exercise in didactic reasoning to support the reliability of any assessment based on it. This is a fundamental requirement. Otherwise, we are dealing with valuations based on arbitrary criteria that violate the principle of legal certainty.

Such reasoning was indeed provided in a report requested in the case of the seizure by the Policía Nacional [National Police] of an Iberian-Roman lion sculpture (Figure 3), possibly from the Asta Regia site (Cádiz), which gave rise to preliminary inquiry No. 238/2016 at the Court of First Instance No. 6 of Granada, in the case known as "Operation Quedada" [23] (p. 17). In an 'oracular' report, the Museo Arqueológico Nacional [Spanish National Archaeological Museum] assessed its value at $€ 30,000$, but the Public Prosecutor's Office requested another expert report from the Conjunto Arqueológico de Carmona [Carmona Archaeological Ensemble] to clarify gaps in the first report, including whether the assessed price was appropriate. Following a detailed phenetic study of the piece [44], it was determined that the probable origin was the aforementioned site (or its area of cultural influence) and that, in light of the value of the insurance purchased for similar pieces held by Andalusian museums, the value of the sculpture should be doubled, to $€ 60,000$, a figure that better reflected the size and good state of conservation of the specimen. Indubitably, the most complicated aspect of that expert report was the need to convincingly explain the change in criteria to better adjust the price to the fact that the artefact in question is in the public domain. 


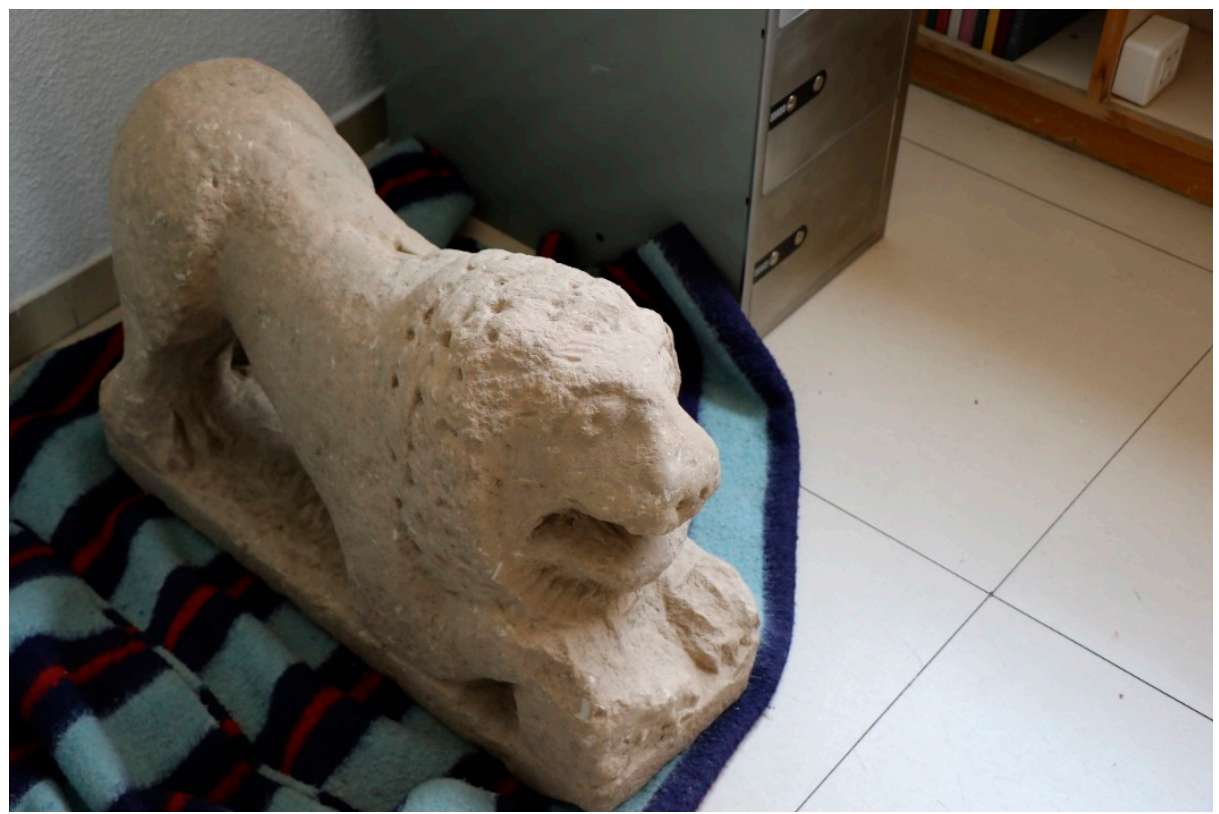

Figure 3. 'Operation Quedada'. Iberian-Roman lion sculpture seized by the National Police (photo by the author).

Unfortunately, such cases are exceptional. In practice, valuation reports for archaeological objects, in both criminal and administrative proceedings, largely remain devoid of convincing rationales for the established amounts. Instead, exploiting the need for the authoritative criteria of specialists, they provide 'oracular' answers, offering no supporting evidence, justification or reasoning for the opinions they contain. The acceptance of these expert reports, which fail to fulfil the basic purpose of any report [45] in judicial or administrative proceedings, can only be understood as the result of a lack of familiarity with the topic by judicial and prosecutorial authorities. In the aforementioned case of the lion, in mistakenly associating the market price with the value of the damage, the Museo Arqueológico Nacional depreciated the piece's economic value. This was recalled in judgement 46/18 of Criminal Court No. 5 of Granada, which tried the case and sentenced the defendants to two years in prison and the definitive confiscation of the lion to be handed over to the Andalusian government.

The case of the so-called 'exceptional finds' allegedly made during the 2005 and 2006 excavation campaigns at the Iruña-Veleia site in Vitoria-Gasteiz exemplifies this 'oracular' approach.

That case involved the forgery of a set of ostraca (engraved potsherds), purported to contain the first evidence of both Christianity and the Basque language in the Basque Country [46] (Figure 4). The exposure of the forgery led to a series of criminal actions against the parties who had claimed to discover the ostraca, thereby perpetrating a massive fraud. In the only outstanding criminal case, the Diputación Provincial de Álava [Provincial Council of Álava] has accused the archaeologists of fraud and damage to archaeological heritage. The Court of First Instance No. 1 of Vitoria-Gasteiz has issued an order to open oral hearings on the understanding that there are reasonable grounds to prosecute these charges. 


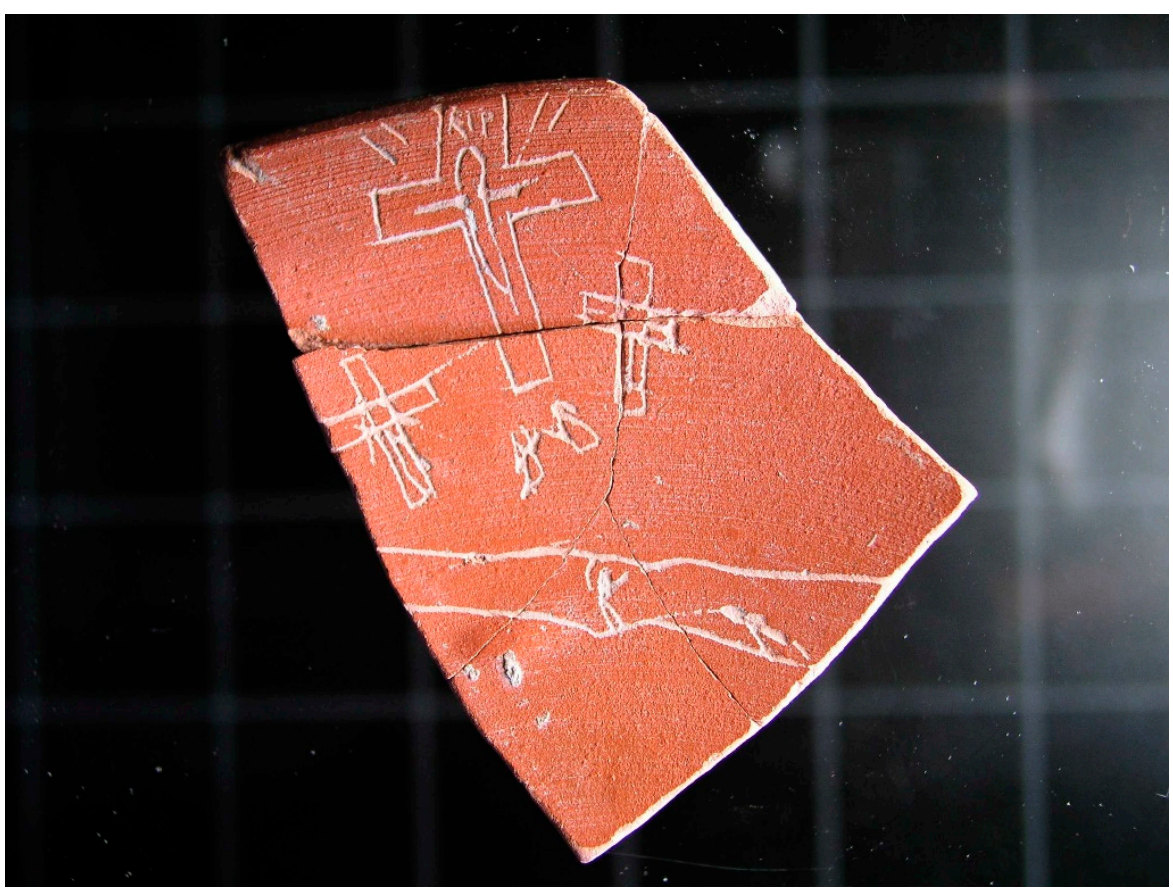

Figure 4. Fake ostraca from the Iruña-Veleia site (Vitoria, Spain) (photo by AFA/DPA).

Of interest here is the expert report assessing the value of the damage. For the experts at the Diputación Provincial, each amorphous sherd of Roman pottery or animal bone that was engraved has an economic value of $€ 600$, bringing the overall cost of the damage to a total of between $€ 240,000$ and $€ 270,000$.

However, in the preliminary inquiry, the archaeological excavation was shown to have been performed in accordance with the usual academic standards. Therefore, the damage was limited to the artificial alteration of some 400 sherds and bone fragments. However, such sherds are practically disposable. In the course of a normal excavation, they are unearthed by the hundreds. Once properly inventoried and catalogued, they are boxed and deposited in the storerooms of a museum until, with the passage of time, they are eventually disposed of for being redundant or insignificant. Since their archaeological value-i.e., the information they contain — had already been documented, the damage was thus negligible, virtually zero.

The rationale provided for that amount is very illustrative. In their report, the experts considered it extremely complex to establish an exact quantification of the total economic value of the damage caused by the 'exceptional graffiti' due to a multiplicity of factors to be considered. The main difficulty lay in the fact that the objects were part of the cultural heritage and their value was primarily historical and scientific and, thus, intangible. They further understood that the damage had been caused not only to the media, but also to the site itself, of which they were part and which is afforded the maximum legal protection. Moreover, their assessment took into account the considerable economic investment made by government authorities and the companies that sponsored the dig. In conclusion, they held that in each and every case the value of the damage would be, if anything, significantly more than $€ 600$ per piece.

So as not to devote too much space to the analysis of this reasoning, suffice it to note the failure to specify sound criteria for the economic quantification. Instead, the report employs vague terms and concepts, such as 'damage to the site', for which it provides no tangible evidence, especially since - as noted - the excavation itself was shown to have been properly performed. Given that the funding provided for the excavation was thus used for its intended purpose, it is likewise hard to understand the allusion to the considerable economic investments to justify the assessment of the damage to the potsherds and bone fragments. For the time being, Section 2 of the Provincial Court 
of Alava has issued order 10/18, of 4 January 2018, adjudicating the appeal against the opening of oral hearings, ruling that the hearings should be held and that there is legal basis for virtually all the criminal charges. However, of interest here is the fact that the appellants argued that some of the engraved potsherds-not including the so-called 'exceptional graffiti' — had a value of zero euros, as they were merely waste from the excavation. In contrast, the defences did not question the Diputación Provincial's appraisal of the set of 'exceptional graffiti', as, unlike the rest of the scientific community, they consider the objects to be authentic and not forgeries [46].

We will have to wait for the oral hearing to gauge the effects of this report. However, it is mentioned here because, in a certain sense, it has already had an effect insofar as it was admitted by the examining magistrate and the Public Prosecutor's Office of Vitoria-Gasteiz.

\section{Damage to Archaeological Sites}

Assessing the value of damage to archaeological sites, usually non-excavated (Figure 5), is the most common case experts face in criminal proceedings brought against the alleged perpetrators of harmful actions, whether wilful or the result of gross negligence.

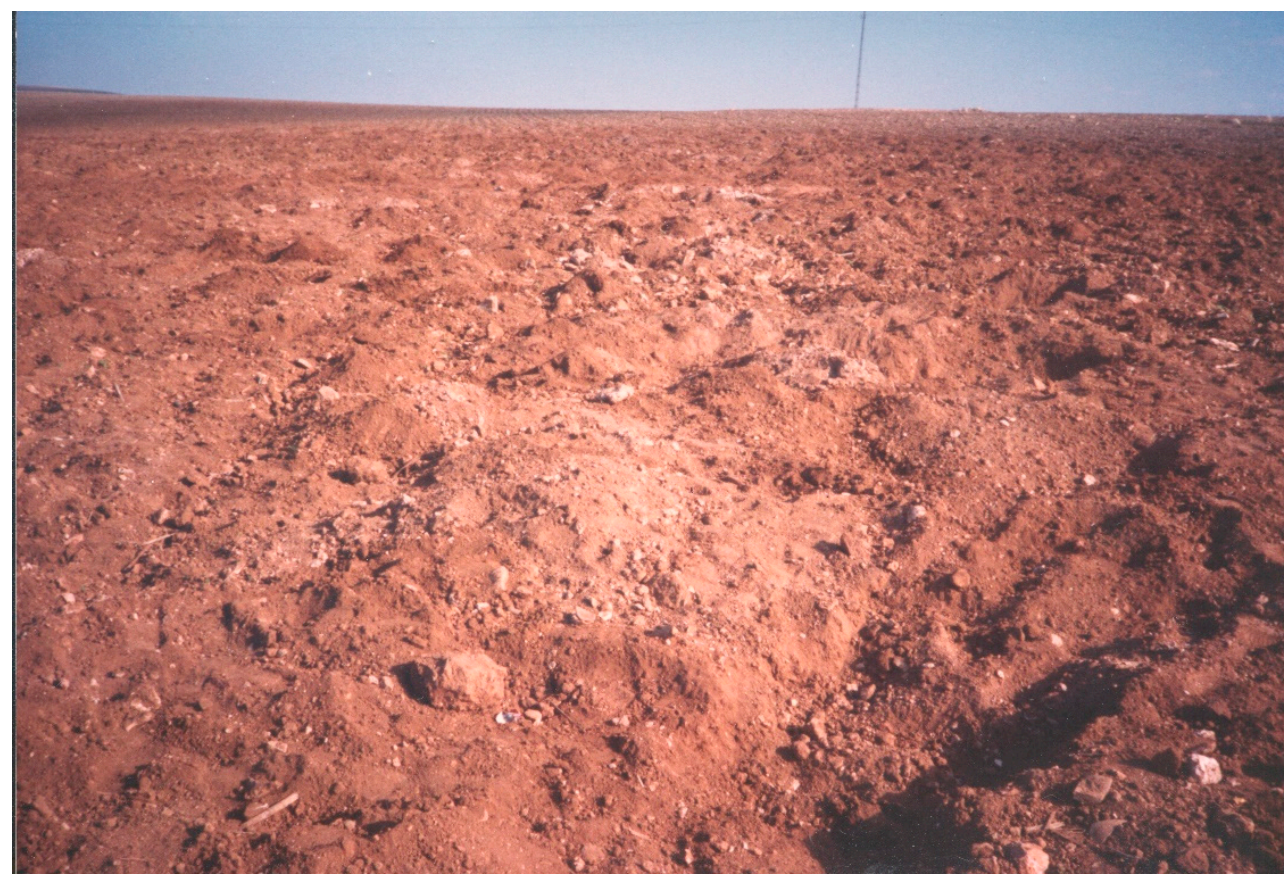

Figure 5. Damage at the Los Cosmes site (Écija, Seville, Spain) (photo by the author).

Despite the frequency of these reports, little has been published on the methods and criteria used. Furthermore, in Spain at least, the theory is not adequately reflected in practice. In the United States, the government agencies responsible for enforcing the 1979 Archaeological Resources Protection Act have spent considerable sums of money to train archaeologists 'to conduct damage assessment and determine commercial and archaeological value', a process that has also been subject to evaluation [47] (p. 222).

The use of this method dates back many years; it may have been one of the first to be used. In the United States, the 1980 Comprehensive Environmental Response, Compensation, and Liability Act (CERCLA) provided for it. Archaeological heritage management has quite naturally adopted the simplest form of a weak sustainability model. Under this model, the depletion of finite resources (archaeological sites) is offset by the production of other artificial goods (the documentation produced by its preventive excavation), providing society with a constant flow of land use, with hardly any drawbacks for the conservation of archaeological heritage [47] (pp. 247-255).

The literature also agrees on the need to include certain types of expenses in the value, such as those for the surveys to calculate the affected area and its depth. However, this cost cannot be identified 
as the value of the damage, as we will see was done in the Mamoa das Chans and Ategua cases below. Other costs associated with restoration work, in cases where the objects could be restored, could also be included. It has been proposed a formula to calculate the value of damage by this method, whose function is merely indicative of the factors to be taken into account in the calculation [24]

$$
V d=(\text { Cexc }+\Sigma \mathrm{Pbb}+\Sigma \text { Gconser } / \text { rest }) \times \Sigma(\text { Isens } 1+\text { Isens } 2+\text { Isens } 3 \ldots)
$$

where $V d$ is the total value of the damage; Cexc is the cost of the archaeological intervention that would have been necessary to record and document the totally or partially destroyed site; $\Sigma \mathrm{Pbb}$ is the sum of the price that could be fetched for the movable and immovable objects that can definitely be identified in the site; ${ }^{6} \Sigma$ Gconser/rest is the cost of the conservation and restoration of movable and immovable objects from or in the damaged area; and $\Sigma$ (Isens1 + Isens $2+$ Isens $3 \ldots$ ) is the sensitivity index of the site in question, expressed as a coefficient. In other words, given the indisputable fact that, whilst all sites are unique and unrepeatable, not all have the same social and historiographical importance, the calculation of the damage must not neglect this reality but rather must translate the difference in the historical interest of each site into a multiplier. As will be seen below, these latter concepts introduce discretionary criteria requiring a very detailed rationale that is usually either omitted entirely or provided only in a highly biased way.

Despite these attempts to provide guidelines for the content and objectives of this type of expert evidence, misunderstandings regarding its purpose and the use of criteria that conflict with what was requested are not infrequent, even when the evidence is admitted in court. The cases of the damage at Mamoa das Chans (Pontevedra) in 2008 and the Ategua site (Cordoba) in 2015 are paradigmatic in this regard. Indeed, the issued reports did not offer an assessment of the damage, but rather of the cost of the excavation required to assess it, which can only be interpreted as a failure to grasp the purpose of this type of report.

In the first case, in judgement no. 210/08, of 30 June 2008, Criminal Court no. 3 of Vigo found the defendant guilty; however, due to the lack of a report establishing the value of the damage, it ended up imposing only a minor fine for civil liability in its decision of 21 March 2011. In contrast, in the second case, even though the expert assessment submitted more accurately reflected the cost of the excavation that would be required to perform such an assessment, in judgement no. 204/2017, of 1 June 2017, Criminal Court no. 4 of Cordoba sentenced the defendants to one year and six months in prison and to pay the Andalusian government, as the party responsible for Andalusian cultural heritage, the sum of $€ 1,051,411.30$. Furthermore, it did this in the absence of any real assessment of the damage wilfully perpetrated at the site, which qualifies for the highest level of protection under Spanish administrative law. This ruling was confirmed in its entirety by the Provincial Court of Córdoba (judgement 440/17, of 19 October 2017). However, the conclusions of law do not address the expert assessment of the damage, as it was not challenged by the defence. Rather, the defence chose to base its case on the defendants' ignorance of the fact that the place was an archaeological site.

This technique, based on the value of the information lost, has proven successful at other times. Such was the case of 'Operation Badía', a police investigation carried out by the Guardia Civil, with the assistance of experts from the regional government of Extremadura [27]. The reports assessed only the value of the minor prospecting by the illegal detectorists that had been documented by the officers without weighing other considerations related to the site's uniqueness. Following a plea bargain, Criminal Court no. 2 of Caceres handed down judgement no. 301/14, of 29 October 2015, sentencing the defendants to pay more than $€ 120,000$ in compensation, the sum of the assessed values of all the small samples taken from various sites. This method of equating the value of the damage with the cost of the information lost seems to be used similarly in the United States [48] (p. 4).

6 In the case of legal systems in which movable archaeological objects are in the public domain, the calculation of this factor should take that circumstance into account. 
In another well-known case, that of the Chaves cave (Huesca), the expert report assessed the damage at slightly over $€ 50,000,000$. However, Criminal Court no. 1 of Huesca sentenced the defendant, accused of destroying the inside of the cave, which had prehistoric deposits and had been subject to systematic digging for years, to two years and six months in prison and payment of a fine of $€ 25,490,805$ for civil liability, as the judge also considered that the government had been negligent in its duties.

The experts who prepared the damage assessment at the request of the examining magistrate [42] used the lost information method. They added the costs of the expert assessment itself, as well as of the excavation that should have been performed to adequately document the site's archaeological potential and that, following the harmful act, was no longer possible. The total amounted to $€ 14,366,141.34$. The result of this assessment was then increased $50 \%$ to account for the 'scientific output costs', i.e., the expenses arising from post-excavation research. An additional $100 \%$ of the previous figure was then added to reflect the site's importance to society. To assure this parameter, two university professors testified at the oral hearing for the trial, vouching for the academic importance of the research conducted at the Chaves cave. One of them described it as "the Barcelona of the Neolithic".

In judgement no. 155/2017, the Provincial Court of Huesca confirmed the judgement of Criminal Court no. 1, but reduced the prison sentence to two years. In the Spanish judicial system, this usually means that the defendant does not go to prison. Like the Criminal Court's original judgement, ${ }^{7}$ its ratification by the Provincial Court attracted the attention of the media, which have presented it as a cautionary tale against the crime of destroying archaeological heritage. ${ }^{8}$

However, a careful reading of the judgements reveals nuances in the judges' eagerness to punish and, especially, in the strategy followed by the defence. First, during the trial the defence failed to submit a reliable alternative expert assessment, leading the judge to accept the one performed by the regional government [42], albeit reducing the amount of civil liability by half. The reasons for this seeming lack of interest can be attributed to two factors: first, that no professionals could be found who were willing to perform an alternative assessment, and, second, undoubtedly, that during the trial the defendant was shown to be insolvent. In other words, he was unlikely to be able to pay the damages being claimed. In this regard, it may also be significant that the judgement of Criminal Court no. 1 recognizes that this person was the de facto administrator of the estate and of companies involved in the cave's destruction; however, precisely the company that had liability insurance, which would have enabled the collection of the amount set in the judgment, was acquitted. In other words, the judge recognized the damage and the liability of this person in the judgement, imposing a prison sentence that he would necessarily have had to serve, as it was greater than two years, and further including a multi-million-euro compensation, in the knowledge that it is unlikely to ever be paid in full.

In the appeal before the Provincial Court, the defence sought, and managed, to reduce the prison sentence. The sentence's potential exemplary impact was thus likewise reduced. Only slightly more than $€ 12,000,000$ has been collected to date in damages, due to the fact that the other company, which was found to be severally liable, gave the estate on which the Chaves cave is located in lieu of payment. Thus, in its order of 29 October 2018, Criminal Court no. 1 decided to suspend the sentence, for all intents and purposes recognizing that no further damages can be collected.

Another case offers insight into a particularity of damage assessments involving ongoing excavations, namely, the in situ restoration of archaeological structures. In March 2015, several individuals entered the dig in Plaza de Armas in the city of Écija (Seville) at night and destroyed various archaeological structures that had been unearthed over the course of the works carried out at the site. Specifically, the main damage was done to a polychrome mosaic showing a little-known Bacchic

7 For example, the Heraldo of 12 November 2016 reported the news with the following headline: "Victorino Alonso, condenado a más de dos años de cárcel por arrasar la cueva de Chaves" [Victorino Alonso, sentenced to more than two years in prison for razing the Chaves cave].

8 Heraldo, 9 January 2018: “La Audiencia ratifica que hubo delito en la cueva de Chaves, pero rebaja la pena a dos años" [The Provincial Court confirms that a crime was committed at the Chaves cave, but reduces the sentence to two years]. 
theme dating from the second century AD (Figure 6). The central panel (emblema), skilfully made from tiny stone and glass-paste tesserae (opus vermiculatum), with a rich polychromy and accomplished shadow play, depicted a dual image, depending on the observer's point of view. From the north of the room, it showed a youth carrying a pedum, or shepherd's crook, over his right shoulder; from the south, it showed a bearded old man carrying a characteristically fringed tympanum, or Bacchic tambourine, in his right hand. The Court of First Instance and Examining Magistrates' Court of Écija opened preliminary inquiry no. 273/2015, asking the Conjunto Arqueológico de Carmona to assess the value of the material damage caused to the site and the costs of repairing it.

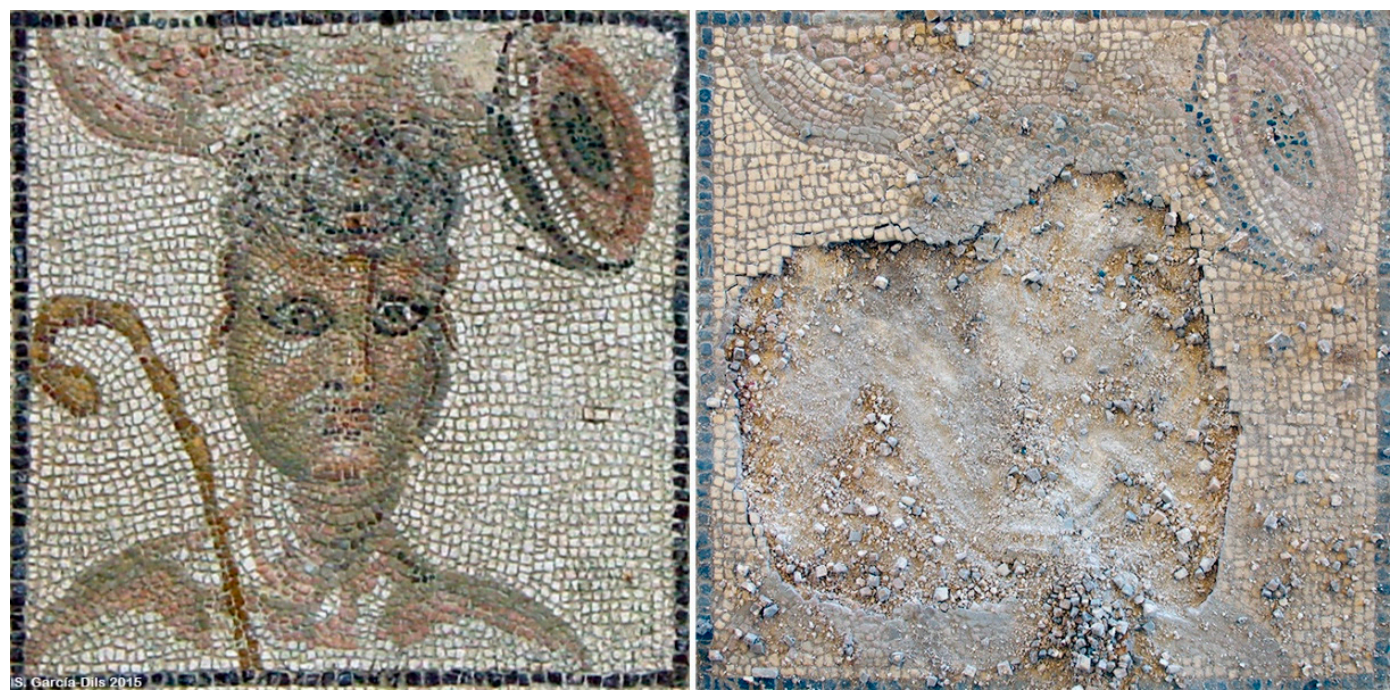

Figure 6. Damage to the mosaic in Plaza de Armas in Écija (Seville, Spain) (photo by the author).

To prepare the report, consideration was given to the social impact of the vandalism on Écija society, for whom the mosaic was a very popular symbol. Indeed, a system of guided tours of the site had been put into place, which the city council, owner of the Plaza de Armas and promoter of the excavations, had outsourced to a company specialized in cultural tours. The news of the attack, in which the tesserae had been prised out of the figures in the central panel, was widely picked up by the national press. ${ }^{9}$

Once the municipal experts had been consulted regarding the possibility of restoring the damaged panel using the original tesserae, which had been recovered by the police when they arrested the culprits, it was concluded that, in this case, certain exceptional circumstances applied. The restoration of archaeological artefacts is governed by principles that tend to limit their reconfigurative possibilities, principles that are not only present in international charters and documents but also in Spanish positive law, specifically, Article 39 LPHE. However, in cases in which the harmful act has caused enormous social distress, it is widely accepted that these constraints may be relaxed and that an intervention intended to restore the damaged artefact to its appearance prior to the impairment can be legitimately undertaken. Otherwise, the socially disruptive consequences of the harmful act would endure and be evoked each time someone saw the mosaic and observed the gap where the central panel had once been. This meant that the assessed value would be considerably higher as such a procedure is much more costly in material and human terms.

Little has been written about these types of court cases, so it is hard to know what criteria are used in other countries. Following the discovery of the looting of the Wanborough site (UK) in 1985 by

9 The agency Europa Press broke the news in an article entitled "Destrozan en Écija un mosaico romano y profanan una tumba árabe" [Roman mosaic destroyed and Arabic tomb desecrated in Écija] on 10 March 2015, the day after the events. 
dozens of detectorists, some of the parties involved in the disaster stood trial. However, due to the impossibility of charging them with criminal damage, since the site was not especially protected, they were acquitted [49]. In other cases in the UK, although they have not been explained in detail, the sole criterion for assessing damage seems to have been the market value [32]. Something similar seems to be standard practice in Estonia [50]. If these references are accurate reflections of how damage is assessed in these countries, there is a clear deficit of valuation criteria and, obviously, the fight against archaeological looting has to overcome an enormous handicap.

Finally, mention should be made of the 'al-Mahdi' case, which has received considerable international attention. The upsurge in destruction in conflict zones and the strategies of attacking cultural monuments followed by Salafi-jihadist groups have elicited a response from bodies that had not hitherto been affected by aggressions against such resources. This particular case involves the recent conviction by the International Criminal Court (ICC) of Ahmad al-Mahdi for his involvement, as a prominent leader of Ansar Dine (a terrorist organization associated with Al Qaeda in the Islamic Maghreb), in the destruction of 10 shrines and mosques in Timbuktu. It was the first time the court had considered that such actions should be classified as war crimes [51,52].

Shortly after the conviction was announced, the Court published the reparations phase calendar, inviting the parties and other institutions to make submissions on the reparations proceedings. The same document also called for the appointment of several experts to assess the damage and set the deadline for the submission of their reports.

In accordance with the extensive account of the case provided by Gutiérrez Zarza [52], special attention should be called to the submissions by the Trust Fund for Victims (TFV) in June 2017. This institution was established by the Assembly of States Party under Article 79 of the Rome Statute. It was created for the victims of crimes falling within the jurisdiction of the ICC and their families. The TFV can join criminal proceedings as a civil party and, following a conviction, can participate in the reparations proceedings, in which it may make general submissions. Once an order for reparations has been issued, it must submit a draft implementation plan, which is subject to the Court's approval. To draw up this plan, it often goes to the country in which the crimes were committed and other places where the victims are. Once the plan has been approved, the TFV actively participates in its implementation.

The TFV's submissions on the merits in the 'al-Mahdi case' included those made by the other parties; however, they also addressed certain aspects of the reparation in a novel way, given the nature of the damage caused in this case, which affects the populations of Timbuktu and Mali in general, but is also of concern to all other countries, given the damaged sites' designation as World Heritage.

The TFV asked the Court for sufficient time to consult with the victims and also meet with spiritual leaders at the site. With regard to this latter aspect, the TFV noted that "reparation must go through the traditional and religious authorities who embody the manna of the ancestors and are the custodians of custom" and that "the involvement of the local traditional and spiritual leaders in the reparation process is paramount".

Regarding the modalities of reparations, the TFV distinguished between modalities to remedy the economic harm suffered and modalities to remedy the moral harm. However, the TFV took a critical view of the submissions filed with regard to the harm that the actions led by al-Mahdi had caused to tourism. The TFV expressed doubt regarding the direct relationship between these acts and the decrease in tourism to Timbuktu, noting that the causes of the decline are manifold and more complex. It further recognized the limited possibilities of restoring Timbuktu's tourism industry to where it had been prior to the destruction of its historical heritage. Notwithstanding the possibility that the court might instruct it to engage with the Malian government to develop tourism programs, it proposed the development of educational and awareness-raising programs to promote the country's valuable cultural heritage, as well as a micro-credit system to assist the local population.

The TFV also weighed in on the possibility of granting monetary or financial compensation to the victims, in accordance with the opinion of those parties who expressed a preference for reparations in 
the form of monetary compensation. Whilst it did not oppose this formula, it did warn of the risk of establishing a dangerous precedent in poor regions with valuable cultural heritage. The possibility of receiving financial compensation could create an incentive for local residents and people in other nearby towns, faced with poverty, to attack cultural heritage sites. Additionally, the TFV noted that such compensation might place the beneficiaries themselves at risk. Even if the financial awards were distributed confidentially, the identity of the beneficiaries would ultimately be discovered by their communities. For both reasons, it suggested that a different, non-financial type of compensation might be more appropriate in this case.

As for the moral harm suffered, the TFV proposed holding certain events to commemorate the destruction of the shrines not only in the city of Timbuktu, but also in other places where displaced victims were located. In its view, the restoration of the mausoleums could not be considered a reparative measure for those people who were physically distant from Timbuktu.

Also with regard to moral harm, the TFV recalled that the crimes committed by al-Mahdi were of "significant gravity" and that they affected the inhabitants not only of Timbuktu, but the entire country and international community. It recommended including, under the modality of symbolic reparations, educational and awareness-raising campaigns on the fact that the destruction of cultural heritage is an international crime and on the economic, cultural, and moral harm such crimes cause.

With regard to al-Mahdi's personal liability, the TFV recalled the court's jurisprudence establishing that, should the convicted person lack the necessary economic means at the time the order for reparations is implemented, it neither displaces nor extinguishes that person's liability for the awards.

\section{Discussion}

The considered cases open a broad debate concerning, at least, four areas. The first is whether the value of a movable object, whether calculated through reference to the market price or any other system, should always be determined based on the object itself or should take into account the damage done to the site from which it was taken. Second, should the presented methodology continue to be used to calculate damages in relation to movable and immovable archaeological heritage or should it be enriched with additions from other fields with which archaeological heritage shares an undeniable connection, in particular, the environment? Third, are there limits beyond which the calculation of damages, regardless of the method, becomes meaningless and other ethical considerations should be used to punish the crimes instead? And, fourth, do such valuations of archaeological objects contribute to the denaturalization of their very cultural essence, their social values, by monetizing them and, if so, to what extent?

\subsection{Assessing Damage to the Sites of Origin of Looted Movable Objects}

In the case of movable archaeological objects included in criminal proceedings for which an economic assessment is requested, the practice of appraising archaeological pieces regardless of their provenience and the damage done to the site from which they were taken should be passed over in favor of including the amount of that damage. Whilst this obviously will not always be possible, in many cases even when the pieces have been recovered by the police somewhere other than the site from which they were taken and not at the time of looting itself. Police practice in Spain is headed in this direction. Many recent police investigations have relied on this method, such as 'Operation Harmakhis', conducted by the Spanish National Police's Historical Heritage Brigade. ${ }^{10}$ As a result of that operation, two people, Jaume Bagot Peix and Oriol Carreras Palomar, have been charged with financing terrorism, membership in a criminal organization, dealing in stolen goods, smuggling, and document forgery in connection with the trafficking of antiquities from various cities

10 El País, March 28, 2018, “Dos detenidos en Barcelona por financiar al ISIS con arte expoliado en Libia” [Two arrested in Barcelona on charges of financing ISIS with looted art from Libya]. 
of ancient Cyrenaica (Libya). In this case, the distinctive features of the funerary sculptures from the region [53], on which the aforementioned criminal charges focus, enabled a plausible ascription of their provenience. The Spanish National Police then requested assistance from the Libyan authorities to confirm the authenticity and origin of the investigated pieces. Their proven in Apollonia and Cyrene sites, two necropolises in Cyrenaica region known to have been looted by terrorist groups, was thus accredited. Additionally, some of the pieces had been damaged and bore marks indicating they had been forcefully extracted from the subsoil. In this regard, current research in the field of 'forensic archaeometry' is seeking to develop scientific techniques to facilitate the determination of the provenience of archaeological objects illicitly extracted from the subsoil and introduced in the international illicit trade [54].

It is worth noting that this shift towards assessing the value of the damage caused by looting and the illicit trade in antiquities in Spain has not taken place at the international level. The identification of the market value of looted artifacts with the value of the damage caused is common in the international literature on illicit antiquities trade. One of the main mantras in studies on this phenomenon is to quantify the amount of money that changes hands due to the illicit trade in archaeological artefacts [55] (p. 16). The figures differ [56,57]; however, what matters here is that this calculation does not consider the value of the damage caused to the archaeological sites, even though in some cases the origin of the artefacts is known, the looted sites have been identified, and there is an approximate idea of the extension of the destruction of them [58].

\subsection{Rethinking Damage Assessment through Environmental Economics}

The existing clash in the examined cases between, on the one hand, the desire to introduce variables to adapt the valuation method used based on the information lost to the importance of each site and, on the other, the discretion in the application of such variables has not been satisfactorily resolved in practice. Literature reviews and expert witnesses can be used to establish certain parameters, such as the chronology, the state of conservation, the potential, the interest of the archaeological ensemble as a whole, the impact of the research conducted at it, its monumentality or its uniqueness, i.e., its cultural capital. However, because these assessments are based solely on the scholarly opinion of a handful of experts, they are biased. To be economically meaningful, they must be opened to a broader segment of society. A conceptual framework and appropriate analytical tools are needed to transform these characteristics into indices with economic consequences, since, as Rizzo and Throsby [12] (p. 987) point out, there is not necessarily a direct proportional relationship between an artefact's popularity and its cultural capital. Mourato and Mazzanti [13] (p. 55) addressed this debate, noting that "maintenance costs are not the correct measure of the benefits derived by society from reduced damage to cultural resources, and the sole consideration of costs may seriously underestimate the true economic values".

In the world of material things, there is a market to regulate that value based on supply and demand. However, with archaeological heritage, not all movable artefacts have a clear, licit market, nor should such a market apply to an entire range of artefacts. Furthermore, with regard to immovable archaeological heritage, especially archaeological sites, certain valuation methods used for environmental assets might be applicable, given the shared characteristics [12] (p. 988). Not only do these methods enable a more comprehensive approach to the social significance of the specific object, they also to some extent ensure the objectivity of the valuations, in which members of society, in addition to experts, participate.

Surveys repeatedly show that people value archaeological heritage [59,60]. Even respondents who say they do not regularly visit archaeological sites and who cannot name any sites in their area are alarmed by the idea of their destruction. This widely shared sentiment is a manifestation of values that can be economically quantified, as in environmental economics [13] (p. 51).

Indeed, these surveys show that large percentages of the population value the mere existence of archaeological heritage, even when they do not personally take advantage of the related services 
or cultural function. They are also able to value its preservation as a future option for themselves or their descendants. A third source of value might stem from the desire to bequeath these assets to future generations.

Thus, the applicability in this matter of the distinction drawn in environmental assessments between market and nonmarket values must be acknowledged. The latter group includes use values (in the form of visitors to sites, readers of history books, viewers of archaeological documentaries, etc.), but also, as noted, 'non-use' values, such as 'indirect use value', 'option value' or 'legacy value'.

The basic principle on which these valuations are based is the measurement of the maximum amount people would be willing to pay for a benefit derived from the archaeological heritage (willingness to pay) or of the minimum amount they would accept as compensation for a cost, understood as the loss of something desirable (willingness to accept). This ideal willingness to pay or to accept compensation is of greater informational value than mere attitudinal judgements [13] (p. 53). The demand for non-market aspects can be analyzed with various methods, primarily concerning revealed and stated preferences. Revealed preferences are those arising from people's actual behavior and they are manifested in surrogate markets.

Revealed-preference methods include the travel cost and hedonic pricing methods. The former assesses a resource based on how much individuals are willing to pay to make the journey to see it. This method uses three main variables: the quality of the resource whose value is being assessed, the number and length of the visits, and the existence of substitute sites. Despite its usefulness, it poses various problems: first, it is only useful in cases requiring significant journeys, and, second, it is based on an assumption that is usually wrong, namely, that the sole purpose of the journey is to visit the resource [12] (pp. $995 \mathrm{ff}$.).

The hedonic pricing method is based on the idea that the price of an asset, usually a home, is conditioned by several factors, including, significantly, culturally rich surroundings. Mourato and Mazzanti [13] (p. 54) believe it has limited applicability in the world of culture. However, for the cases under study here, it could be considered in instances of the assessment of damage to urban archaeological heritage in cities such as Mérida or Tarragona, in which the archaeological heritage is a key cultural asset. In any case, this method, in conjunction with the contingent valuation method, has been applied with very interesting results in the Netherlands to monetize the benefits of investments in conservation [61].

Given the difficulty of finding data from an appropriate market, valuations have largely focused on stated preferences, mainly using the contingent valuation method. This method uses survey responses to determine the willingness to pay to access a resource or to accept compensation for its loss. Since it was first introduced as a perfectly viable valuation method for trials, in relation to the claims filed in the wake of the Exxon Valdez oil spill in Alaska in 1989, its use has been subject to broad debate, especially with regard to preventing response biases in order to make the valuations more objective $[12,13,62,63]$. Its methodology, consisting of several steps, was fairly well-established by the National Oceanic and Atmospheric Administration (NOAA) [64]. In the field of archaeological heritage, its use is usually linked to assessing the viability of projects or the usefulness of conservation investments [65], although it has also been used in North Carolina to assess the economic value of protecting shipwrecks against treasure-hunting companies [66], a use similar to that called for in this paper.

Notwithstanding the undeniable usefulness of this method for assessing the value of damage to archaeological sites, it too poses problems that cannot be ignored. First, the design of such surveys surpasses the professional competencies of archaeologists. To ensure that they are suitable and do not fall prey to the main deviations and biases that tend to plague them, they would need to be prepared by a team including not only archaeologists, but also economists and sociologists. Cultural authorities and professional archaeologists do not usually have such a human resource infrastructure on hand. Nor do courts usually request assessments from multidisciplinary teams, requiring them to work together. Second, even if remote survey methods are used, such as e-mail surveys or online polls 
on social media, conducting such a survey still requires a certain amount of time that may not be compatible with the calendar of a trial.

Neither problem has an easy short-term fix, at least in the current Spanish context. Not only must an extensive prior effort be made to convince people of the need for such assessments, resources to facilitate the work are required as well. In this regard, it would be extremely useful for cultural authorities to commission contingent valuation studies of sites in the various situations provided for by law-known, presumed, and unknown — at both the regional and provincial level. This would enable the creation of a database that, appropriately maintained to reflect changes in the consumer price index, could be used as a reference to objectively calculate the indices and premiums to be applied in the valuation of damage at archaeological sites.

Given that this proposal will presumably increase the assessment of damage to archaeological artefacts, the figures from such a database would likewise need to be modulated in accordance with other parameters, so as not to violate the principle of proportionality between the sentence and the offence (Article $114 \mathrm{CP}$ ).

\subsection{The Limits: Damage to Archaeological Heritage as a War Crime}

Current global events daily bring news of the destruction, intentional or otherwise, of monuments, destruction that is no longer merely the collateral damage of an armed conflict, but the main goal thereof. However, these unfortunately frequent images have taken on new overtones in the asymmetric conflicts involving radical Salafi-jihadist groups. Although these minority groups primarily direct this violence against Muslims themselves, part of their modus operandi includes attacking monuments that are symbols of universal heritage. To maximize the coverage of these acts of vandalism, they film them and share them on social media. It is not so much a provocation or the execution of a religious commandment as the desire to cause consternation in the West, which is, after all, their main enemy $[67,68]$.

These situations seem to call for the use of the methods for assessing social damages discussed in this paper. Given the importance of the affected objects, reasons can be found to apply all the valuation methods. However, in these cases, the uncertainty is great and the consequences are quite difficult to analyze. They are cases in which the cultural damage cannot always be compensated with an economic sum [69] (p. 38). Here, perhaps, it is worth again recalling the revised concept, rooted in Crocian thought, of 'incalculable value'. Discussing the limits of the application of the contingent valuation method, Bruno Frey [70] (p. 36) gave a comparable example: "[i]t makes less sense to evaluate the benefits and costs of preserving, say, the Colosseum or (by now) the Eiffel Tower, because it is unimaginable that they would be torn down-or if, for some reason, a demolition were planned, a Contingent Valuation study would not change anything".

In any case, it is easy to imagine a situation of economic insolvency that would prevent the vast majority of leaders of these extremist groups from paying any potential monetary award. The 'al-Mahdi case' discussed above, like others, such as that of the Buddhas of Bamiyan (Afghanistan) [67] (p. 28) or the damage caused by US soldiers in Babylon during the 2003 invasion of Iraq [71], show that, following these conflicts, the cost of reparations tends to be borne by international institutions, donor countries or altruistic companies, and the possibility of collecting these resources from the actual perpetrators of the damage is very slim.

\subsection{The Commodification of Archaeological Heritage}

Archaeology is currently embroiled in a deep debate: many professionals are watching the commodification of archaeological objects with fear [72-74]. A deeper exploration of the terms of this debate exceeds the scope of this paper; suffice it to say that it is driven by resistance to allowing archaeological heritage to be consumed in the neoliberal practice spearheaded by the proponents of a hegemonic politically conservative ideology. This questioning aims to restore the significance of archaeological heritage and make it freely accessible to society, as a resource for reflection and personal 
education, an instrument for cultural enrichment, something that is largely lost when it becomes a commodity for rapid consumption. I believe this clamor is grounded in an ethical plane perfectly compatible with the practice of protecting this legacy. Although none of the texts cited here addresses the issue of archaeological looting, based on their philosophical positions, one could conclude that the authors would agree that the economic value of movable and immovable archaeological objects is incalculable. This consideration brings us back to the start of this paper, regarding the need to monetize that value in most cases in which an action, whether wilful or negligent, causes damage to such objects and the risks of failing to do so. As I hope to have shown in this paper, the concept of the 'incalculable value' of the damage caused to archaeological objects is not incompatible with the economic quantification of the perpetrators' financial liability for the reparations to remedy both the physical and moral harm caused by their actions.

\section{Conclusions}

This paper has examined the state of play of a practice-assessing damage to movable and immovable archaeological objects - that is quite frequent, despite having received little attention in the literature. Through the presentation and discussion of several cases, I hope to have convinced readers of the need to rethink assessment techniques.

In the case of seized movable artefacts, I believe the separate, individualized valuation of archaeological pieces should be ruled out, even when the exact provenance is unknown. In the aforementioned case of the seized late Roman lion sculpture, it was possible to establish the area of origin of the piece quite plausibly. As we have seen, it was not an isolated case; many of the objects seized in 'Operation Tertis' still bore soil from the site from which they had been taken. Taking into account the number of pieces and their characteristics (whether they come from sealed deposits, such as funerary offerings, or are decorative pieces from a monument, etc.), one can apply the same concept of reparation costs used for sites, reformulated, as described, based on the valuation methodologies used in environmental economics. In 'Operation Harmakhis' the damage done to the necropolis should be included, even if the Spanish defendants did not commit it.

In other cases in which this inference cannot be made, the various circumstances of the legal regime governing movable archaeological heritage must be taken into account. Furthermore, the rationale for the assignment of a specific monetary value must be explicitly stated.

The ideal formula for calculating the value of damage to archaeological sites would be the sum of several items. The first would be the restoration expenses, including those arising from the archaeological activity that would have been needed to document the area affected by the harmful action. These expenses would include the verification surveys and graphic representations, as well as the study and dissemination thereof. They would also include the estimated cost of restoring damaged objects at excavated sites. Finally, they should include the costs of adapting the natural environment and taking measures to protect and replace the vegetation cover or soil to prevent subsequent damage from natural causes. However, these items alone do not cover the damage caused to the site. In addition to its own material nature and the information it holds, the value of the site also includes the social esteem felt for it, which must be factored in as a weighting index or additional sum.

Using the contingent valuation methodology, despite its difficulty, to establish the added value of the damaged object makes it verifiable for all interested parties in the proceedings. This ensures the legal guarantees that must be insisted upon in all criminal proceedings, in order to reduce arbitrariness and the imposition of an expert sensibility that is foreign to that of society at large.

The current course has, at best, a very short future. The weighting indices that have been used, in the Spanish cases, can be easily refuted in court proceedings; because they are not based on any particular methodology, they violate the universally applicable principle of legal certainty. The purpose of this principle, which can be invoked in any proceedings, is precisely to prevent uncertainty or the arbitrary application of legal concepts and precepts to the detriment of the individual. Someone accused of causing damage could argue, fairly easily, against these criteria, which multiply or qualify 
the costs of reparation. Such a decision would jeopardize not a possible guilty verdict, but the application of a suitably modulated punishment scheme and the assignment of monetary liability for that person's acts, thereby depriving society of its ability to obtain justice. Additionally, the case of the Chaves cave suggests that, for now, although the will to punish these types of crimes may exist today in Spain, the sentences imposed and damages to be paid by the perpetrators will remain within moderate parameters.

Situations of armed conflict pose a challenge not so much to the applicability of these formulas as to their ultimate usefulness.

Funding: This paper was made possible by R\&D Project DER2016-74841-R: “Instrumentos jurídicos en defensa de la integridad de los bienes arqueológicos" [Legal instruments in defence of the integrity of archaeological heritage], funded by the Spanish Ministry of Economy and Competitiveness for the 2017-2019 period.

Conflicts of Interest: The author declares no conflict of interest.

\section{References}

1. Riegl, A. El culto Moderno a los Monumentos Antiguos. Caracteres y Origen; Visor: Madrid, Spain, 1987; Original edition, Leipzig 1903.

2. Croce, B. Problemi di Estetica; Laterza \& Figli: Bari, Italy, 1954.

3. Taruffo, M. La Prueba; Marcial Pons: Madrid, Spain, 2008.

4. Franceschini, F. (Chair of the Committee). Relazione de la Commisione d'indagine per la tutela e la valorizzazione del patrimonio storico, archeologico, artistico e del paesaggio. Riv. Trimest. Dirit. Pubbl. 1966, $1,119-244$

5. Giannini, M.S. I beni culturali. Riv. Trimest. Dirit. Pubbl. 1976, 1, 3-38.

6. Alonso Ibáñez, M.R. El Patrimonio Histórico. Destino Público y valor Cultural; Civitas: Madrid, Spain, 1992.

7. Renart García, F. El delito de Daños al Patrimonio Cultural Español. Análisis del artículo 323 del Código Penal de 1995; Comares: Granada, Spain, 2002; p. 324.

8. García Calderón, J. La Defensa Penal del Patrimonio Arqueológico; Dickinson S.L.: Madrid, Spain, 2016; pp. 123-126.

9. O'Keefe, P.J.; Prott, L.V. Law and the Cultural Heritage. Discovery and Excavation; Professional Books: Oxford, UK, 1984; Volume I.

10. Barcelona Llop, J.; Cisneros Cunchillos, M. Vestigios y Palabras. Arqueología y Derecho del Patrimonio Arqueológico; Universidad de Cantabria: Santander, Spain, 2017.

11. Rufino Rus, J. La Protección del Patrimonio Arqueológico en el Código Penal. Deficiencias y Propuestas para una Reforma de las Leyes Sustantivas y Procesales. PH. Bol. Inst. Andal. Patrim. Hist. 2012, 82, 54-70.

12. Rizzo, I.; Throsby, D. Cultural Heritage: Economic Analysis and Public Policy. In Handbook of the Economics of Art and Culture; Ginsburgh, V., Throsby, D., Eds.; Elsevier: New York, NY, USA, 2006; Volume 1, pp. 983-1016. [CrossRef]

13. Mourato, S.; Mazzanti, M. Economic Valuation of Cultural Heritage: Evidence and Prospects. In Assessing the Values of Cultural Heritage. Research Report; The J. Paul Getty Trust: Los Angeles, CA, USA, 2002; pp. 51-76.

14. Guisasola Lerma, C. La protección penal del Patrimonio Cultural en el Derecho Comparado. In Tres Estudios Jurídicos sobre el Patrimonio Histórico; Junta de Andalucía: Sevilla, Spain, 2005; pp. 79-127.

15. Rando Casermeiro, P. La Distinción entre el Derecho Penal y el Derecho Administrativo Sancionador. Un análisis de Política Judicial; Tirant lo Blanch: Valencia, Spain, 2010.

16. Núñez Sánchez, A.M. La nueva regulación penal del delito de expolio de yacimientos arqueológicos. In La nueva Regulación Penal del delito de Expolio de Yacimientos Arqueológicos; Guisasola Lerma, C., Ed.; Tirant lo Blanch: Valencia, Spain, 2018; pp. 154-186.

17. Rodríguez Temiño, I.; Yáñez, A. Los procedimientos sancionadores por uso no autorizado de detectores de metales. Reflexiones sobre una práctica imperfecta. In El expoliar se va a Acabar. Uso de detectores de metales y arqueología: Sanciones administrativas y penales; Yáñez, A., Rodríguez Temiño, I., Eds.; Tirant lo Blanch: Valencia, Spain, 2018; pp. 281-334.

18. Salinero Alonso, C. La Protección del Patrimonio Histórico en el Código Penal de 1995; Códex: Barcelona, Spain, 1997; p. 315. 
19. Núñez Sánchez, A.M. El expolio de yacimientos arqueológicos. In La lucha contra el tráfico ilícito de Bienes Culturales; Ministerio de Cultura: Madrid, Spain, 2008; pp. 175-204.

20. Ortiz Sánchez, M.; Pérez Pino, V. Diccionario Jurídico Básico; Editorial Tecnos S.A.: Madrid, Spain, 2012.

21. Roma Valdés, A. La valoración de los daños arqueológicos y la justicia cautelar en el proceso penal. PH. Bol. Inst. Andal. Patrim. Hist. 2012, 82, 71-74.

22. García Calderón, J. La relación del patrimonio histórico con el derecho penal. In La Lucha Contra el Tráfico Ilícito de Bienes Culturales; Ministerio de Cultura: Madrid, Spain, 2008; pp. 67-86.

23. Guisasola Lerma, C. Delitos contra bienes culturales: Una aproximación al concepto de expolio en el Derecho Penal. Rev. Gen. Derecho Penal 2017, 27, 1-28.

24. Rodríguez Temiño, I. Propuesta para la valoración de daños en yacimientos arqueológicos. Patrim. Cult. Derecho 2012, 16, 275-293.

25. Cortés Ruiz, A. Actuaciones policiales contra expolios arqueológicos. In La protección del Patrimonio Arqueológico Contra el Expolio; Junta de Andalucía: Sevilla, Spain, 2002; pp. 61-78.

26. Rodríguez Temiño, I. Indianas Jones sin Futuro. La lucha contra el Expolio del Patrimonio Arqueológico; JAS Arqueología SLU: Madrid, Spain, 2012; pp. 317-325.

27. Morales Bravo de Laguna, J. La Guardia Civil y la lucha contra el expolio arqueológico. Cuad. Prehist. Arqueol. Univ. Granada 2015, 25, 31-48.

28. Tamayo Isasi-Isasmendi, J.A. La comisión de expropiación de bienes de valor artístico y arqueológico. Rev. Admin. Públ. 1965, 47, 95-126.

29. García de Enterría, E. Consideraciones sobre una nueva legislación del patrimonio artístico, histórico y cultural. Rev. Española Derecho Admin. 1983, 39, 575-591.

30. Querol Fernández, M.A.; Martínez Díaz, B. La gestión del Patrimonio Arqueológico en España; Alianza Editorial: Madrid, Spain, 1996.

31. Bland, R. The Trasure Act and the Portable Antiquities Scheme: A case study in developing public archaeology. In Public Archaeology; Merriman, N., Ed.; Routledge: London, UK, 2004; pp. 272-291.

32. Wilson, P.; Harrison, M. Three years on from 'The Nighthawking Survey': Innovations in heritage protection. Internet Archaeol. 2013, 33. [CrossRef]

33. Rodríguez Temiño, I. Teoría y práctica de los hallazgos arqueológicos. Patrim. Cult. Derecho 2010, 14, 171-190.

34. Ashenfelter, O.; Graddy, K. Art Auctions. In Handbook of the Economics of Art and Culture; Ginsburgh, V., Throsby, D., Eds.; Elsevier: New York, NY, USA, 2006; Volume 1, pp. 909-945. [CrossRef]

35. Fernández-Galiano, D.; Patón Lorca, B.; Batalla Carchenilla, C. Mosaicos de la villa romana de Carranque: Un programa iconográfico. In IV Coloquio Internacional Sobre el Mosaico Antiguo; Junta de Castilla y León: Valladolid, Spain, 1994; pp. 317-326.

36. Vázquez Paz, J.; Garrido González, P. (Eds.) El tesoro del Zaudin: Contextualización Arqueológica del Conjunto Numismático Tardoantiguo de Tomares (Sevilla); Junta de Andalucía: Sevilla, Spain, 2017.

37. Casado Ariza, M.J. El tesoro acuñado en titulares: El impacto mediático del tesoro del Zaudín. In El tesoro del Zaudin: Contextualización Arqueológica del Conjunto Numismático Tardoantiguo de Tomares (Sevilla); Vazquez Paz, J., Garrido González, P., Eds.; Junta de Andalucía: Sevilla, Spain, 2017; pp. 351-374.

38. Flecker, M. The ethics, politics, and realities of maritime archaeology in Southeast Asia. Int. J. Nautical Archaeol. 2002, 31, 12-24. [CrossRef]

39. Rodríguez Temiño, I. The Odyssey Case: Press, public opinion and future Policy. Int. J. Nautical Archaeol. 2017, 46, 192-201. [CrossRef]

40. Díaz Martínez, S. Acciones de conservación aplicadas a 25000 piezas numismáticas en plata, recuperadas del hundimiento de la fragata Nuestra Señora de las Mercedes. Informes Trabajos 2015, 13, 159-168.

41. Throckmorton, P. The World's Worst Investment. The Economics of Treasure Hunting with Real-Life Comparisons. In Maritime Archaeology: A Reader of Substantive and Theoretical Contributions; Babits, L.E., Van Tilburg, H., Eds.; Springer: New York, NY, USA, 1998; pp. 75-83.

42. Romeo, F.; Royo, J.I.; Gonzalvo, I.; Angas, J.; Fatás, L. Un nuevo sistema para la valoración económica de los daños en yacimientos arqueológicos expoliados. Patrim. Cult. Derecho 2017, 21, 231-268.

43. Brodie, N. Provenance and price: Autoregulation of the antiquities market? Eur. J. Crim. Policy Res. 2014, 20, 427-444. [CrossRef]

44. Chapa Brunet, T. La Escultura Zoomorfa ibérica en Piedra; Universidad Complutense: Madrid, Spain, 1981.

45. Rodríguez Temiño, I. Informes que informen. PH. Bol. Inst. Andal. Patrim. Hist. 2012, 82, 81-82. 
46. Rodríguez Temiño, I. The 'exceptional finds' of Iruña-Veleia (Álava): Syntax of an archaeological forgery. Zephyrus 2017, LXXIX, 197-217. [CrossRef]

47. Palmer, R. Federal Prosecutions under the Archaeological Resources Protection Act of 1979: A Ten-Years Review (1996-2005). In Yearbook of Cultural Property Law 2007; Hutt, S., Tarler, D., Eds.; Left Coast Press: Walnut Creek, CA, USA, 2007; pp. 221-237.

48. Dosi, C. Environmental Values, Valuation Methods, and Natural Disaster Damage Assessment; United Nation Economic Commission for Latin America and the Caribbean United Nation Economic Commission for Latin America and the Caribbean: Santiago de Chile, Chile, 2001.

49. Graham, D. To change the law: The story behind the Treasure Act 1996. Surrey Archaeol. Collect. 2004, 91, 307-314.

50. Ulst, I. Combating Illicit metal detecting in Estonia. AP J. 2013, 3, 21-28.

51. San Martín Calvo, M. La sanción penal internacional de los crímenes de guerra contra los bienes culturales. El asunto "Ahmad al-Mahdi". Rev. Española Estudios Int. 2016, 8, 218-251.

52. Gutiérrez Zarza, Á. Tráfico ilícito de bienes culturales y cooperación penal europea e internacional. In Delitos Contra el Patrimonio Histórico. Especial Referencia al Patrimonio Arqueológico; Centro de Estudios Jurídicos: Madrid, Spain, 2017; in press.

53. Belzic, M. Les sculptures funéraires de Cyrénaïque sur le marché de l'art. Libyan Stud. 2018, 48, 105-116. [CrossRef]

54. Rodríguez Temiño, I.; Yáñez, A.; Jorge-Villar, S.E.; Reyes Mateo, Á.; Rufino Rus, J.; Salas Álvarez, J.; Lavín Berdonces, A.C. Forensic Archaeometry Applied to Antiquities Trafficking: The Beginnings of an Investigation at the Frontiers of Knowledge. Arts 2018, 7, 98. [CrossRef]

55. Brodie, N.; Doole, J.; Watson, P. Stealing History: The Illicit Trade in Cultural Material; McDonald Institute: Cambridge, UK, 2000.

56. Calvani, S. Frequency and figures of organized crime in Art and Antiquities. In Organised Crime in Art and Antiquities; Manacorda, S., Ed.; ISPAC: Milano, Italy, 2009; pp. 29-40.

57. Passas, N.; Bowman Proulx, B. Overview of Crimes and Antiquities. In Crime in the Art and Antiquities World: Illegal Trafficking in Cultural Property; Manacorda, S., Chappell, D., Eds.; Springer: New York, NY, USA, 2001; pp. 51-68.

58. Hanna, M. Documenting Looting Activities in Post-2011 Egypt. In Countering Illicit Traffic in Cultural Goods. The Global Challenge of Protecting the World's Heritage; Desmarais, F., Ed.; ICOM: Paris, France, 2015; pp. 47-64.

59. Pokotylo, D.; Guppy, N. Public Opinion and Archaeological Heritage: Views from Outside the Profession. Am. Antiquity 1999, 64, 400-416. [CrossRef]

60. Ibáñez Alfonso, M.A. Percepción y usos del Patrimonio Arqueológico de Sevilla; Universidad de Sevilla: Sevilla, Spain, 2014.

61. Ruijgrok, E.C.M. The three economic values of cultural heritage: A case study in the Netherlands. J. Cult. Herit. 2006, 7, 206-213. [CrossRef]

62. Bateman, I.J.; Willis, K.G. (Eds.) Valuing Environmental Preferences. Theory and Practice of the Contingent Valuation Method in the US, EU, and Developing Countries; Oxford University Press: Oxford, UK, 1999.

63. Noonan, D.S. Contingent Valuation and Cultural Resources: A Meta-Analytic Review of the Literature. J. Cult. Econ. 2003, 27, 159-176. [CrossRef]

64. Lipton, D.W.; Wellman, K.; Sheifer, I.C.; Weiher, R.F. Economic Valuation of Natural Resources. A Handbook for Coastal Resources Policymakers; NOAA Coastal Ocean Program Decision Analysis Series No. 5; NOAA Coastal Ocean Office: Silver Spring, MD, USA, 1995.

65. Beltrán, E.; Rojas, M. Diversified funding methods in Mexican archaeology. Ann. Tour. Res. 1996, $23,463-478$. [CrossRef]

66. Whitehead, J.C.; Finney, S.S. Willingness to Pay for Submerged Maritime Cultural Resources. J. Cult. Econ. 2003, 27, 231-240. [CrossRef]

67. Francioni, F.; Lezerini, F. The Obligation to Prevent and Avoid Destruction of Cultural Heritage: From Bamiyan to Iraq. In Art and Cultural Heritage: Law, Policy, and Practice; Hoffman, B.T., Ed.; Cambridge University Press: New York, NY, USA, 2006; pp. 28-40.

68. Echevarría Jesús, C. La Nueva Dimensión del Desafío Yihadista Salafista; Universidad del País Vasco/Euskal Herriko Unibertsitateko: Bilbao, Spain, 2015. 
69. Hanemann, W.M. Valuing the Environment Through Contingent Valuation. J. Econ. Perspect. 1994, 8, $19-43$. [CrossRef]

70. Frey, B.S. The Evaluation of Cultural Heritage: Some Critical Issues. In Economic Perspectives on Cultural Heritage; Hutter, M., Rizzo, I., Eds.; Palgrave MacMillan: New York, NY, USA, 1997; pp. 31-49.

71. Bahrani, Z. The Battle of Babylon. In The Destruction of Cultural Heritage in Iraq; Stone, P.G., Bajjaly, F.J., Eds.; Boydell \& Brewer Ltd.: Woodbridge, UK, 2008; pp. 165-172.

72. Hamilakis, Y.; Duke, P. (Eds.) Archaeology and Capitalism. From Ethics to Politics; Left Coast Press: Walnut Creek, CA, USA, 2007.

73. Almansa Sánchez, J. Trading archaeology is not just a matter of antiquities: Archaeological practice as a commodity. In Ethics and Archaeological Practice. Ethical Archaeologies; The Politics of Social Justice 1; Gnecco, C., Lippert, D., Eds.; Springer: New York, NY, USA, 2015; pp. 141-157.

74. Aparicio Resco, P. (Ed.) Archaeology E Neoliberalism; JAS Arqueología SLU: Madrid, Spain, 2016.

(C) 2019 by the author. Licensee MDPI, Basel, Switzerland. This article is an open access article distributed under the terms and conditions of the Creative Commons Attribution (CC BY) license (http:/ / creativecommons.org/licenses/by/4.0/). 